\title{
Financial Integration, Competition and Bank Risk-Taking Behavior: Evidence from Africa's Sub-Regional Markets
}

\author{
Kannyiri Banyen ${ }^{1+}$ \\ ${ }^{1}$ Simon Diedong Dombo University of Business and Integrated Development Studies, Ghana
}

\begin{abstract}
Financial integration is generally associated with the development of synergies through cross-border banking and investment activities and increased competitiveness among banks. This paper examines the effects of shifts in financial freedom and competition on bank risk-taking behavior using data from 405 banks in 47 African countries across five regional economic communities from 2007-2014. The core findings suggest that financial integration directly increases bank risk-taking behavior in Africa through rising competition. The results also support an inverted U-shaped relationship between competition and bank risk-taking behavior. However, disparities in the results across sub-regional markets suggest that financial integration policies must be tailored to suit the market characteristics of each regional bloc. Overall, the study identifies deficiencies in competitiveness as a fundamental variable that hinders banks' ability to benefit from the opportunity of stability offered by financial integration in emerging economies.
\end{abstract}

Keywords: Financial Integration, Bank Competition, Risk-Taking Behavior, Africa

JEL Classifications: F36, F65, G21, N27

Received 27 February 2020, Revised 5 August 2020, Accepted 28 January 2021

\section{Introduction}

Risk is an inherent aspect of the banking business, and the effect of financial integration and changes to competition on banking stability is a central issue in the active debate among academics, practitioners, and policymakers in the financial services industry. This debate is even more critical for emerging economies, given the prevalence of information asymmetry in largely underdeveloped and bank-dominated financial systems (Bourgain et al., 2012). Additionally, excessive bank risk-taking poses a threat to bank profitability and survival and imperils the stability and productivity of economies overall (Schoemaker, 2011).1) Following the recent global financial crisis, the debate has largely centered on the role played by financial integration in the crisis and how future such occurrences can be averted.

Generally, banking supervision is guided by the fundamental principle that actors' distortion of the bank market structure pose a threat to banking stability through influencing the risk-taking 
conduct of individual banks (Marcus, 1984; Keeley, 1990). In view of this, financial integration, which facilitates the mobility of capital and financial intermediaries across national borders, is identified by the extant literature as a key factor that imperils the stability of banks (Keeley, 1990; Farroukh, 2013; Cabillas \& González, 2014). In spite of these assertions, empirical evidence on the relationship between financial integration and bank fragility has failed to achieve consensus, and can only be described as contentious, at best.

Largely heralded as a vital catalyst for enhancing economic growth, most African countries and other developing economies embraced financial integration as a panacea to address the need for capital accumulation, allocation, and other development challenges (Beck \& Cull, 2014). This sentiment fomented the adoption of major regulatory reforms in favor of financial integration in most African countries beginning in the mid-1980s. Despite these and other benefits claimed, Africa's financial integration has the potential to erode the charter value of individual banks and reduce their ability to charge monopoly rents (Keeley, 1990). Affected banks may react by either adopting innovative and efficient banking practices (Boyd \& de Nicoló, 2005; Berger et al., 2009) or engaging in risky conduct (Keeley, 1990; Rupello, 2004) to maintain their profit profiles (Fiordelisi \& Mare, 2014). A third strand of the literature suggests a non-linear relationship between integrated banking and risk-taking behavior (Martinez-Mierra \& Repullo, 2010; Jiménez et al., 2013). Growing tensions in the empirical literature following the global financial crisis, makes it crucial for regulators and policymakers in economic blocs seeking greater financial integration to empirically examine the influence of financial integration on the level of competition in banking sectors and how such integration impacts bank risk-taking behavior and general economic stability. Nonetheless, the empirical literature has not yet examined how financial integration, particularly financial freedom and regional cross-border banking, shape bank risk-taking behavior in Africa through the channel of competition.

In this paper, I analyze the effects of financial integration and changes in competition on bank risk-taking behavior using a panel dataset comprising 405 banks from 47 African countries operating across five regional economic communities (RECs) ${ }^{2}$ ) for the 2007-2014 period, as it reflects banks' competitive conduct in response to market structure changes resulting from growing financial freedom and cross-border banking in the region (Farroukh, 2013). The study is necessitated by both the lack of agreement in the literature on the possible influence of financial integration, bank competition, and bank risk-taking behavior (Keeley, 1990; Boyd \& de Nicoló, 2005; Beck et al., 2006; Martinez-Mierra \& Repullo, 2010; Jiménez et al., 2013;

1) The recent global financial crisis, which ostensibly originated from unbridled risk-taking behavior of key financial intermediaries, provides evidence in support of this view (Schaeck \& Cihák, 2014).

2) These include the Arab Maghreb Union (AMU), the East African Community (EAC), the Economic Community of Central African States (ECCAS), the Economic Community of West Africa States (ECOWAS), and Southern Africa Development Community (SADC). Table A in the Appendix presents the list of countries and the number of banks in each REC. 
Goetz, 2017; Norman et al., 2018) and the paucity of literature on the effect of Africa's progressive financial integration on banking stability (Moyo et al., 2014).3) To the best of our knowledge, no single study on Africa has empirically examined the role of financial freedom and cross-border banking on the possible correlation between bank competition and risk-taking behavior, nor has there been any attempt made to distinguish between the direct effect and the indirect effects that may occur through the channel of bank competition. Therefore, fixed and random effects models 4 ) are applied to an unbalanced panel of 405 banks from 47 African countries across five regional economic communities to examine the potential effect of financial freedom and cross-border banking on competitiveness and risk-taking behavior of African banks. I also examine whether variations in financial freedom and cross-border banking and their interaction with variations in bank market structure reduces bank risk-taking behavior. These relationships are further tested for each of the five regional economic communities amidst an array of controls.

The paper contributes to the literature on bank risk-taking is several ways. First, the paper provides new empirical evidence on the correlation between financial integration, competition changes, and bank risk-taking behavior in Africa, especially for five clusters RECs in the region. To the best of our knowledge, this is the first paper to conduct a comprehensive sub-regional comparison of these relationships. Second, I provide support for the stabilizing role of financial integration in banking markets through the channel of competition. The findings of the study support the view that in competitive banking markets, increased financial freedom and cross-border participation drives banks toward greater stability. Our findings further suggest that an existing lack of competitiveness in Africa's banking sector could account for the region's inability to benefit from the potential stability offered by financial integration. Examination of the moderating role of financial integration on the competitive conduct of banks has significant policy implications for achieving an optimal approach to address the trilemma between promoting greater financial integration and bank competition without increasing bank and economic instability.

The remainder of the paper is organized into five sections. Section 2 presents a brief overview of financial markets in Africa, with emphasis on the banking sector. Section 3 scrutinizes the pertinent literature. Section 4 describes the research methodology, whereas Section 5 presents and discusses the empirical results. Section 6 concludes the paper.

3) For instance, though some studies examine the potential correlation between competition and bank fragility in Africa (Amidu and Wolfe, 2013; Brei et al., 2018), very few have investigated the link between financial integration and bank risk-taking behavior (Motelle and Biekpe, 2014; Moyo et al., 2014; Sissy et al., 2017). These studies largely fail to examine the trilemma between deeper financial integration, bank competition, and bank stability in Africa.

4) Discussion is based on the Hausman specification test results. 


\section{Overview of Africa's Financial Markets}

Over the past three decades, many African countries have adopted major financial sector reforms to encourage the mobility of capital and financial intermediaries within and across national borders to enhance competitiveness, efficiency, and stability for greater economic growth. Despite some improvement, the literature largely asserts that African financial markets remain poorly developed, highly uncompetitive, and extremely volatile in comparison to most other regions of the world (Beck et al., 2011; Beck \& Cull, 2014; Moyo et al., 2014; Amidu \& Wolfe, 2013; Leon, 2016; Banyen \& Biekpe, 2020). In recognition of these constraints, in 1980, the African Union took steps to establish an African Economic Community (AEC) ${ }^{5}$ ) (Ndomo, 2009). This decision led to the establishment of a mosaic of regional economic communities, largely based on proximity and geographic region. Notably, the agreements and treaties that shape these regional economic communities (RECs) allow for overlapping memberships due to political incongruities and other strategic socioeconomic factors, thus hindering the overall integration agenda of the AEC.

According to Banyen and Biekpe (2020), successful financial integration largely depends on the scope and speed of reforms, the compliance of participating countries, and the effects of such integration on the conduct and performance of financial intermediaries. However, existing literature on financial integration in Africa reveals that despite some successes at the sub-regional level, the speed and scope of Africa's financial integration remains behind that of other regions of the world (Beck \& Cull, 2014; Moyo et al., 2014). Figure 1 shows that, for the period 2007-2014, while the global financial freedom index averaged around $49.75 \%$, Africa's was $42.65 \%$, compared to $42.93 \%$ for Asia-Pacific, $50.95 \%$ for the Americas, and $64.30 \%$ for Europe. Major variations also existed across and within Africa's sub-regional markets. Figures 1 and 2 demonstrate that South African Development Community (SADC) member countries had the most liberalized financial markets in Africa, recording an average financial freedom index of $50.80 \%$ over the $2007-2014$ period. This was followed by the East African Community (EAC), at 49.97\%; the Economic Community of West African States (ECOWAS), at $46.12 \%$; the Economic Community of Central African States (ECCAS), at $36.69 \%$ and the Arab Maghreb Union (AMU), at 34.18\%.

Indeed, the small scale, fledgling nature of national financial markets and institutions in Africa increases market opacity and resultant adverse selection problems in the banking sector. Figure 1B reveals that Sub-Saharan Africa is among the most volatile financial sectors in the

5) This was later modified by the so-called Abuja Treaty of 1991; however, a resolution was not passed by the OAU Council of Ministers to commence its implementation until 1994. In effect, the treaty partitioned the AEC into five sub-regional communities comprised of North, West, South, East and Central Africa, with the view of establishing the AEC over a 34-year period spanning 1994 to 2027 (Ndomo, 2009). 
world. Over the 2007-2014 period, Africa largely maintained the second most volatile banking sector globally, only performing better than the European Union and Central Asia. Additionally, Table 1 demonstrates that average bank insolvency and credit risks are generally high, with major variations across the sub-regional markets.

Figure 1. Financial freedom index in Africa: Inter-REC summary

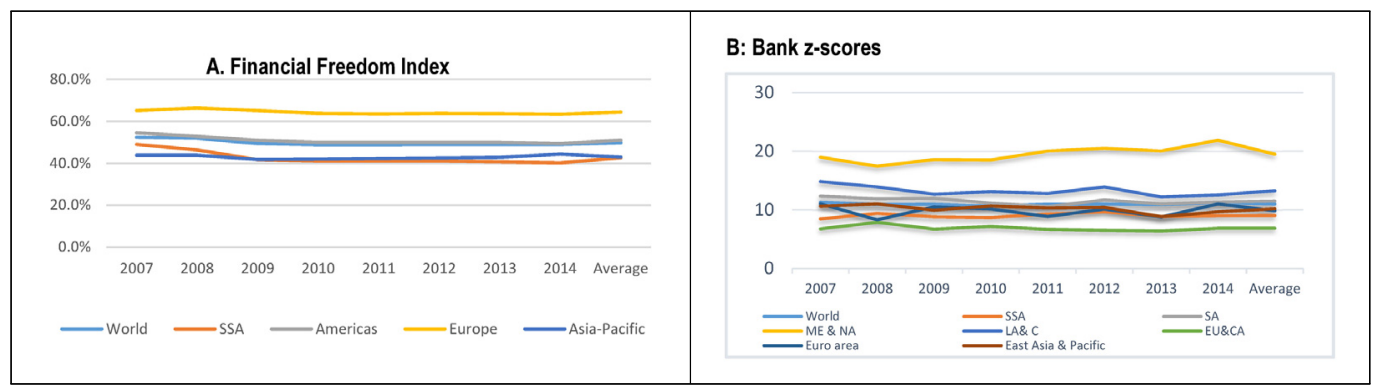

(Sources) (A) Author's summary of data from the Economic Freedom Database of the Heritage Foundation (2016) and (B) Author's computation from the World Bank's Global Financial Development Database (2016).

Figure 2. Financial freedom index in Africa: Intra-REC summary

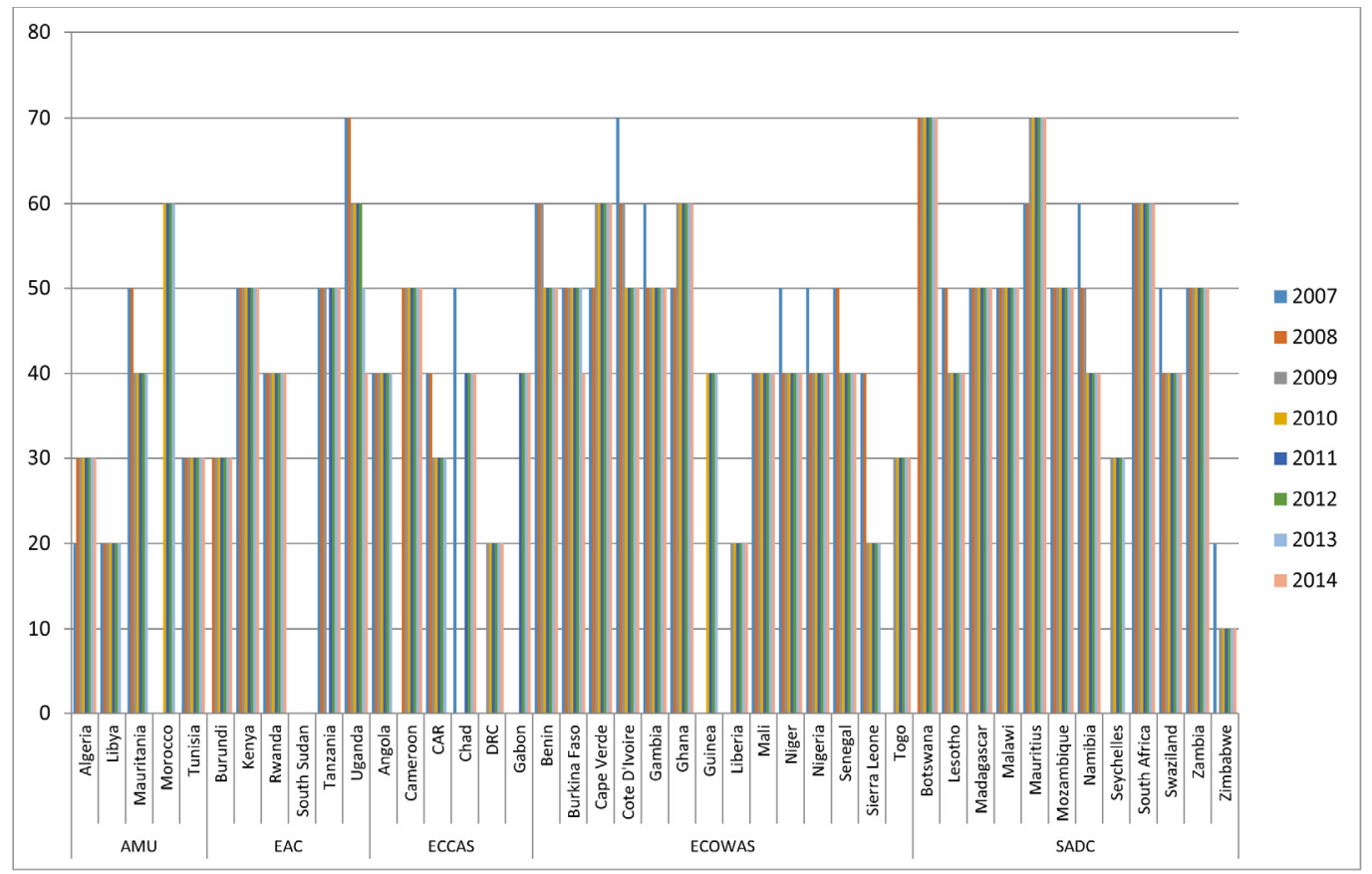

(Source) Authors' calculations from Heritage Foundation's Economic Freedom Database (2016).

In view of the foregoing evidence, I hypothesize that current market conditions in Africa's banking sector have the potential to significantly influence the risk-taking behavior of banks 
in the region, particularly across sub-regional markets. It is therefore imperative that policymakers and practitioners continuously evaluate the effects of Africa's ongoing financial integration processes and guide appropriate initiatives to ensure a robust and stable banking sector to advance ongoing economic growth. This sub-regional evidence will enhance consensus building towards a holistic harmonization of Africa's financial markets for greater regional development.

\section{Literature Review}

The paper is motivated by ongoing lack of consensus in the literature regarding the effects of financial integration on bank stability, coupled with the paucity of literature on the effects of Africa's economic integration process. The literature6) on the effect of financial integration on bank risk-taking behavior largely disagrees regarding the underlying effects of the correlation between competition and stability. The "franchise-value" paradigm contends that in stimulating higher competition among banks, financial integration promotes risk-taking behavior (Marcus, 1984). This perspective of "competition-fragility" suggests that such financial freedom promotes both foreign and domestic participation, contracting bank charter value, clogging the ability to charge monopoly rents, and forcing engagement in risky activities to maintain profit profiles. In contrast, "competition-stability" perspective contend that rather than increasing bank fragility, such competitive pressure promotes greater stability through pushing banks to become more innovative and efficient. Indeed, Boyd and de Nicoló (2005) demonstrated that in periods of rising competitive pressure, banks employ cost-leadership and differentiation strategies to gain a higher market share of profits without sacrificing their stability (Lui et al., 2012). Additionally, lower intermediation spreads reduce bank default risks (Beck et al., 2006). A third strand of the literature contends that the relationship is non-linear, as earlier theories suggest, but is U-shaped (Caminal \& Matutes, 2002). According to Martínez-Miera and Repullo (MMR) (2010), as competition increases, banks enhance efficiency and reduce risk profiles up to an optimum threshold, beyond which additional increases in competition lead to increased risk-taking.

Studies examining the determinants of bank-risk-taking behavior are also rife with disagreements. All of the following studies support the franchise-value theory, among others: Agoraki et al. (2011), for 546 banks from 13 Central and Eastern European economies; Beck et al. (2013), for a cross-country sample of 17,055 banks from 79 countries; Tabak et al. (2015), for the Brazilian banking sector; Soedarmono and Tarazi (2016), for 686 banks from 12 Asia-Pacific countries from 1994-2009; Shijaku (2017), for 16 Albanian banks for 2008-2015; Kabir and Worthington (2017) for banks from 16 developing economies from 2000-2012. Others, such

6) See Cubillas and Gonzalez (2014) and Hamdaoui, Zouari and Maktouf (2016) for more comprehensive reviews of studies on financial integration and bank stability. 
as Turk-Ariss (2010), for 821 banks from 60 developing countries for 1999-2005; Fu et al. (2014), for 14 Asia-Pacific economies from 2003-2010; Schaeck and Čihák (2014) for 3,325 European banks for 1995-2005; Kasman and Kasman (2015), for the Turkish banking industry from 2002-2012; and Goetz (2017), for the United States banking sector, provide evidence in support of the "competition-stability" perspective. Also, in support of the MMR theory, Berger et al. (2009), for 23 developing countries; Tabak et al. (2012) for 10 countries from 2003-2008; Jiménez et al. (2013), for 107 commercial and savings banks in the Spanish banking sector; and Brei, Jacolin, and Noah (2018) for 221 banks in 33 Sub-Saharan African countries from 2000-2015, all identified a U-shaped or non-linear relationship between competition and bank risk-taking behavior.

Studies focusing on the role of financial integration in shaping bank risk-taking behavior elicit similar contentions. For instance, whereas Rossi (1999) and Joyce (2011), among others, assert a negative relationship between financial integration and bank risk-taking behavior. Others, such as Bourgain et al. (2012), Cubillas and González (2014), Smaga (2014), and Li and Su (2016) maintain that the relationship is positive, and that deeper financial integration promotes bank risk-taking. In contrast, based on evidence from a sample of 49 countries from 1980-2010, Hamdaoui et al. (2016) contend that the relationship between financial integration and bank fragility is an inverted U-shape. Notably, these studies failed to account for the channels through which financial integration determines bank risk-taking behavior, constraining the practical application of their findings. To remedy this shortcoming, several recent studies have examined competition and other channels through which financial integration affects bank risk-taking behavior. For instance, Cubillas and González (2014) empirically examined the stability effect of financial integration through the competition channel using data from 4,333 banks from 83 developed and developing countries for 1991-2007. They found that although the full sample results confirmed the competition-fragility perspective, the effect through the competition channel are found to only be significant in developed countries, whereas deeper financial integration in developing countries affected bank fragility through the creation of so-called opportunities for greater risk-taking. In addition, Farroukh (2013) found that financial integration and bank competition changes positively influence bank risk-taking behavior in 13 Middle Eastern and North African (MENA) countries for 1980-2009. However, after studying 180 Southeast Asian banks from 1990-2014, Norman et al. (2018) contend that bank regulation has a moderating effect of reducing bank risk-taking, despite rising competition in a banking system.

Studies on the effect of Africa's financial integration have also largely failed to empirically assess the effect of financial integration on bank fragility through the channel of bank competition. For instance, previous studies on the effects of financial integration on the banking sector of Africa by the World Bank (2007), the African Development Bank (2010), Motelle and Biekpe (2014), Moyo et al. (2014), Leon (2016), and Sissy et al. (2017) all failed to distinguish between 
the direct and indirect effects on bank risk-taking behavior or to account for the moderating role of integration in shaping the competition-fragility correlation of banking in Africa. Specifically, evidence on the interactive effects of financial integration and bank competition changes in determining bank risk-taking conduct in Africa seem non-existent. There also appears to be no single recent study explaining the sub-regional disparities in the effect of financial integration on the bank competition-fragility correlation in Africa.

In sum, whereas financial integration may generate positive effects on the competitiveness and efficiency of banks in emerging markets through lower intermediation cost, innovation, and efficiency, its effects on bank stability are not always desirable. The scanty empirical studies on the effect of Africa's financial integration process amid the ongoing tensions in the theoretical and empirical literature therefore highlights an urgent need for this study. These relationships are tested with an array of controls. The findings are expected to provide insights to guide policy decisions and actions and to promote peer-learning within Africa's RECs.

\section{Methodology}

To examine the effect of financial integration and competition on bank risk-taking behavior, this study estimates the following model following the work of Agoraki et al. (2011) and Farroukh (2013):

$$
R_{i t}=\alpha+\beta_{1} F I_{j t}+\beta_{2} L_{i t}+\beta_{3}\left(L_{i t}\right)^{2} \sum_{k=1}^{n} \gamma_{k} X_{i t}+\sum_{l=1}^{m} \phi_{l} M_{j t}+\lambda_{i}+\epsilon_{i j t}
$$

where $R_{i, t}$ denotes bank $i$ 's risk-taking behavior at time $t$, interchangeably proxied using bank Z-score and non-performing loans ratio; $j$, indexes country; $F I_{j t}$ denotes financial integration, proxied by the financial freedom index of the Heritage Foundation (2015), while $L_{i t}$ denotes bank market structure, proxied by the Lerner Index. Referencing Martinez-Mierra and Repullo (MMR) (2010), Fu et al. (2014), and Norman et al. (2018). I include a quadratic term of the Lerner Index $\left(L_{i t}\right)^{2}$ to capture possible nonlinear effects of market structure on bank risk-taking: $\alpha, \beta, \gamma, \phi, \theta$ are estimated parameters, whereas $X_{i, t}$ and $\mathrm{M}_{\mathrm{j}, \mathrm{t}}$ are vectors of bank and country level controls, respectively. $\lambda$ represents unobserved individual bank effects, whereas $\varepsilon_{\mathrm{iit}}$ is the idiosyncratic error term. Descriptive statistics of these variables are presented in Table 2.

Following Agoraki et al. (2011), Farroukh (2013), and Norman et al. (2018), a multiplicative interaction term of financial freedom and the Lerner Index are included to account for the effect of financial integration on bank risk-taking behavior through the competition channel. According to Brambor et al. (2006), failure to account for such an interactive effect may limit 
the practical application of research findings. Therefore, the basic model is extended to include the interaction term as follows:

$$
R_{i, t}=\alpha+\beta_{1} F I_{j, t}+\beta_{2} L_{i, t}+\beta_{3}\left(L_{i, t}\right)^{2}+\beta_{4}\left(F I_{j, t}^{*} L_{i, t}\right)+\sum_{k=1}^{n} \gamma_{k} X_{i, t}+\sum_{l=1}^{m} \phi_{l} M_{j, t}+\lambda_{i}+\epsilon_{i j, t}
$$

where all variables are as defined in Equation 1 except the multiplicative interaction term $F I_{j t} * L_{i t}$.

Following the extant literature,7) Equations 1 and 2 are estimated using static panel models. Farroukh (2013) argued that applying the fixed effects model helps account for time and country fixed effects on the risk-taking behavior of banks. However, as our study is a comparative study, and the Hausman specification test failed to choose one specification for all samples, results are included in the analysis for both fixed and random effects models. The discussion is based on the results of the model chosen through the Hausman test, unless otherwise stated. The interpretation of the findings follows the work of Brambor et al. (2006), Farroukh (2013), and Norman et al. (2018). I concentrate on the coefficients $\beta_{1}, \beta_{2}$ and $\beta_{3}$ for evidence of the effects of financial integration, bank competition, and the quadratic form of bank competition on bank risk-taking behavior, respectively. The coefficient of the multiplicative interaction term $\left(\beta_{4}\right)$ provides evidence of the effect of financial integration in a competitive banking system. For instance, since the z-score measures distance from insolvency and higher values denote greater stability, positive and significant values of $\beta_{1}$ and $\beta_{2}$ in either Equation 1 or 2 implies that financial integration and bank competition, respectively promotes bank stability. However, if the dependent variable is the NPL ratio, since a higher NPL ratio implies higher bank risk-taking behavior, positive and significant values of $\beta_{1}$ and $\beta_{2}$ will imply a negative effect of financial integration and competition on bank stability. In Equation 2, a positive and significant value of $\beta_{4}$ is evidence that financial integration promotes bank stability in a competitive banking environment and the reverse is true for the NPL ratio. Additionally, in both Equations 1 and 2, a negative and significant value of $\beta_{3}$ when $\beta_{2}$ is positive indicates that the relationship between bank competition and risk-taking is an inverted $U$.

Following the extant literature, ${ }^{8}$ ) two widely used proxies of bank risk-taking behavior are employed in the analysis. First, z-score serves as the primary proxy of bank insolvency risk. According to Norman et al. (2018), z-score measures the number of standard deviations a bank's ROA must drop below its expected value before its equity is depleted. Following Soedarmono et al. (2013), a bank's z-score is computed as follows:

7) See Agoraki et al. (2011) and Farroukh (2013), among others.

8) See Jiménez et al. (2013), Amidu and Wolfe (2013), Goetz (2017), and Norman et al. (2018), among others. 


$$
Z_{i, t}=\frac{R O A_{i, j, t}+E Q T A_{i, j, t}}{\delta R O A_{i, j, t}}
$$

where $Z_{i, t}$ is bank i's insolvency risk at time $\mathrm{t}$ and higher z-score values imply lower insolvency risk or greater bank stability; EQTA $\mathrm{ijt}_{\mathrm{ijt}}$ represents a bank's capitalization measured as the ratio of total equity to total assets; $\mathrm{ROA}_{\mathrm{ijt}}$ is a bank's return on assets; and $\delta \mathrm{ROAi}_{\mathrm{t}}$ is the standard deviation of a bank's return on assets. To normalize the distribution and allow for more optimal estimations, the work of Norman et al. (2018), among others, is followed, using the natural logarithm of the computed $\mathrm{z}$-scores for the empirical analysis.

Additionally, the log-odds transformation of a bank's nonperforming loans ratio (NPLR) is measured as the ratio of total impaired loans to gross loans to proxy for bank intermediation risk. This measures the quality of loans and reveals a bank's propensity to lend to subprime or risky borrowers (Goetz, 2017). NPLR is mathematically defined as:

$$
N P L R_{i, t}=\ln \left(\frac{N P L \text { ratio }_{i, t}}{1-N P L \text { ratio }_{i, t}}\right)
$$

where NPLR is the log odds transformation of the NPL ratio of bank $\mathrm{i}$ in year $\mathrm{t}$ and higher value means higher bank credit risk.

To measure competition, the study follows the work of Amidu and Wolfe (2013) to estimate bank market power using the Lerner Index. The Lerner Index measures a bank's market power by calculating its markup of prices over marginal cost (Berger et al., 2009) as follows:

$$
L_{i t}=\frac{\left(A R_{i t}-M C_{i t}\right)}{A R_{i t}},
$$

where $L_{i t}$ is bank i's Lerner Index in year $t ; R_{i t}$ and $M_{i t}$ are average revenue and marginal cost, respectively. Average revenue measures the price of total assets, derived as total revenue/total assets, whereas the marginal cost is the percentage change in total cost resulting from producing one more units of output. Following Cubillas and González (2014), the following transcendental logarithmic cost function are estimated to derive the marginal cost, $\mathrm{MC}_{\mathrm{i}, \mathrm{t}}$ :

$$
\begin{aligned}
& \ln \left(\operatorname{Cost}_{i t}\right)=\beta_{0}+\beta_{1} \ln \left(Y_{i t}\right)+\frac{1}{2} \beta_{2} \ln Y_{i t}^{2}+\sum_{k=1}^{3} \delta_{k} \ln W_{k, i t}+\sum_{k=1}^{3} \frac{1}{2} \delta_{4} \ln W_{k, i t}^{2}+\sum_{k=1}^{3} \delta_{k i} \ln y_{i t} \ln w_{k, i t} \\
& +\sum_{k=1}^{3} \sum_{j=1}^{3} \delta_{k j} \ln \left(W_{k, i t}\right) \ln \left(W_{j, i t}\right)+\phi_{1} \ln Z_{i t}+\frac{1}{2} \phi_{3} \ln Z_{i t}^{2}+\phi_{2} \ln Y_{i t} \ln Z_{i t} \\
& +\sum_{k=1}^{3} \phi_{k i} \ln W_{k, i t} \ln Z_{i t}+\varsigma T+\epsilon_{j}
\end{aligned}
$$


The above specification assumes that bank i's total costs in year $\mathrm{t}$ is a function of one standard bank output $\mathrm{Y}_{\text {it }}$ and three input prices $\mathrm{W}_{1}, \mathrm{~W}_{2}$ and $\mathrm{W}_{3}$, respectively. In reference to Amidu and Wolfe (2013) and Cubillas and González (2014), bank output is proxied by total assets, whereas input prices include prices of labor, funding, and fixed capital, respectively. $\mathrm{T}$ represents the deterministic time trend, capturing general time-related changes in technology (Berger et al., 2009). Also, following Coccorese (2014), equity capital $\left(Z_{i t}\right)$ is included as an additional control to account for the possibility that capital is used by a bank as a source of funding (Hughes \& Mester, 1993; Coccorese, 2014). Also, referring to the convention in the work of Coccorese (2014), all factor prices and total operating cost are divided by the price of deposits to impose homogeneity of degree one in the input prices. Marginal cost $\left(\mathrm{MC}_{\mathrm{ijt}}\right)$ is estimated using the first derivative of the translog cost function with respect to output as follows:

$$
M C_{i, t}=\frac{\operatorname{cost}_{i, t}}{y_{i, t}}\left[\beta_{1}+\beta_{2} \ln y_{i, t}+\sum_{k=1}^{2} \lambda_{k} \ln W_{k, i, t}+\phi_{2} \ln \left(Z_{i, t}\right)\right]
$$

The value of the Lerner Index is interpreted as the market power of each bank in each year, with higher values denoting higher pricing power and lower competitive market conditions (Amidu \& Wolfe, 2013).

Financial integration (FI) is measured using country level estimates of the degree of financial freedom from the Heritage Foundation Economic Freedom database (2015). The financial freedom index measures a country's degree of financial openness, accounting for freedom of participation by both foreign and local banks, and the level of freedom financial markets and institutions have from government regulation. Higher values of the index indicate greater financial freedom. In line with the competition-stability literature, financial freedom is assumed to significantly increases bank stability if the banking sector is competitive.

To isolate the impact of financial integration and competition changes on bank risk-taking behavior, a set of bank and macroeconomic controls based on the literature are introduced. Bank level controls include management quality, bank size, capitalization, loan ratio, loan quality, and revenue diversification. First, management quality, measured as total operation cost-to-income ratio, is expected to positively correlate with bank risk-taking, as higher values denote lower cost efficiency (Fiordelisi \& Mare, 2014; Schaeck \& Cihák, 2014). Bank size, measured as the natural logarithm of total assets, has no consensus regarding the effect of bank risk-taking behavior (Tabak et al., 2012). However, in Africa's embryonic banking systems, size is expected to negatively affect bank risk-taking due to the relatively small sizes of banks in the region, which hardly enjoy a "too big to fail" condition to warrant unchecked risk-taking behavior. Moreover, in nascent markets, larger banks are better able to diversify asset portfolios 
to mitigate risk in comparison to smaller banks (Norman et al., 2018). The ratio of total equity to total assets proxies bank capitalization and it is expected to improve bank stability by cushioning banks against the effects of losses (Moyo et al., 2014). Loan ratio, measured as the ratio of gross loans to total assets, reflects bank lending behavior in reaction to competition changes from a more liberalized financial system, and is expected to positively affect bank risk-taking (Kasman \& Kasman, 2015). Asset quality is proxied using a ration of loan loss reserves to gross loans. This measures potential default risk and is expected to positively correlate with risk-taking (Norman et al., 2018).

Macroeconomic controls included in the study are annual per capita GDP growth rates and inflation rates. Annual per capita GDP growth rates account for income growth and portends individuals' ability to pay debts (Faroukh, 2013; Fu et al., 2014), whereas inflation rate accounts for the effect of macroeconomic volatility (Cubillas \& González, 2014; Norman et al., 2018). Per capita GDP growth is expected to negatively impact bank risk-taking, whereas inflation rate positively influences bank risk-taking. Two additional variables of control of corruption and regulatory quality are included, to assess the effect of institutional quality on the relationship between financial integration, competition, and bank risk-taking behavior. Both variables are expected to improve bank stability in Africa (Farroukh, 2013).

Data for the study was collected from 405 banks from 47 African countries across five regional economic communities for 2007-2014. The bank level data is collected from the Bankscope database of Bureau Van Dijk (2015) and comprises detailed unconsolidated financial statements. The banks were selected based on the availability of data on Bankscope for at least half of the study period. The macroeconomic data was sourced from the World Development Indicators (WDI) database of the World Bank Group (2016), whereas data on the financial freedom index (FINFREE) was collected from the Economic Freedom Index database of the Heritage Foundation (2016). Our sample is further divided into five groups based on regional economic community membership to allow a sub-regional comparison of these relationships. Overall, the unbalanced panel contains 2,834 bank-year observations from the 405 banks sampled.

\section{Empirical Results}

Table 1 presents the summary statistics for the regression variables, whereas Table 2 shows the pairwise correlation between these variables. Table 1 reveals that bank competition in Africa is very low, as average Lerner Index from 2007-2014 was 0.267 across all 47 countries sampled. Additionally, the AMU is found to be the least competitive among the sub-regional banking markets, with an average Lerner Index of 0.347 , followed by ECCAS (0.309), SADC (0.269), ECOWAS (0.266), and EAC (0.206). In contrast, Table 1 shows that bank solvency risk in 
Africa is generally low, as average z-scores are high, at 27.120 for all countries under study, the AMU banking system demonstrating the highest stability levels, with z-scores averaging at 68.664. In addition, SADC, EAC, and ECOWAS recorded averages of 22.874, 20.234 and 19.127, respectively, with the ECCAs recording the lowest average z-score of 16.643 for the study period. Non-performing loans are also found to be highest in ECOWAS $(8.00 \%$ of total

Table 1. Summary Statistics

\begin{tabular}{|c|c|c|c|c|c|c|c|c|c|c|c|c|c|}
\hline \multirow{2}{*}{ Sample } & \multicolumn{3}{|c|}{ AFRICA } & \multicolumn{2}{|c|}{ AMU } & \multicolumn{2}{|c|}{ EAC } & \multicolumn{2}{|c|}{ ECCAS } & \multicolumn{2}{|c|}{ ECOWAS } & \multicolumn{2}{|c|}{ SADC } \\
\hline & Mean & SD. & $\mathrm{N}$ & Mean & SD. & Mean & SD. & Mean & SD. & Mean & SD. & Mean & SD. \\
\hline z-score & 27.12 & 78.21 & 2834 & 68.66 & 206.26 & 20.23 & 17.38 & 16.64 & 15.99 & 19.13 & 18.76 & 22.87 & 21.23 \\
\hline NPLR & 0.05 & 0.09 & 2816 & 0.04 & 0.07 & 0.06 & 0.07 & 0.03 & 0.06 & 0.08 & 0.13 & 0.04 & 0.07 \\
\hline FI & 45.24 & 13.09 & 2702 & 34.18 & 11.93 & 49.97 & 7.45 & 36.69 & 10.04 & 46.12 & 11.00 & 50.80 & 16.01 \\
\hline LI & 0.27 & 0.20 & 2354 & 0.35 & 0.19 & 0.21 & 0.17 & 0.31 & 0.24 & 0.27 & 0.22 & 0.27 & 0.19 \\
\hline CIR & 0.86 & 2.78 & 2825 & 1.21 & 6.89 & 0.93 & 2.48 & 0.86 & 1.06 & 0.76 & 0.25 & 0.75 & 0.66 \\
\hline Size & 13.18 & 1.67 & 2834 & 14.45 & 1.67 & 12.23 & 1.21 & 12.97 & 1.43 & 13.14 & 1.45 & 13.03 & 1.73 \\
\hline CAR & 0.13 & 0.11 & 2834 & 0.15 & 0.18 & 0.15 & 0.09 & 0.13 & 0.11 & 0.11 & 0.10 & 0.14 & 0.10 \\
\hline LoanR & 0.48 & 0.19 & 2834 & 0.56 & 0.27 & 0.50 & 0.15 & 0.44 & 0.17 & 0.48 & 0.17 & 0.50 & 0.20 \\
\hline LonQ & 0.02 & 0.04 & 2816 & 0.01 & 0.03 & 0.01 & 0.02 & 0.02 & 0.04 & 0.02 & 0.05 & 0.01 & 0.02 \\
\hline Divers & 0.36 & 1.89 & 2825 & 0.11 & 4.88 & 0.42 & 0.10 & 0.40 & 0.15 & 0.39 & 1.12 & 0.41 & 0.26 \\
\hline GDPGPC & 2.89 & 7.00 & 2834 & 2.21 & 16.70 & 2.62 & 4.23 & 2.68 & 5.39 & 3.17 & 3.41 & 2.99 & 3.07 \\
\hline Inflation & 68.38 & 1212.6 & 2829 & 4.26 & 2.60 & 9.98 & 6.44 & 7.63 & 5.57 & 6.86 & 6.75 & 287.83 & 2603.4 \\
\hline $\mathrm{CC}$ & -0.58 & 0.56 & 2834 & -0.50 & 0.38 & -0.74 & 0.45 & -1.21 & 0.22 & -0.56 & 0.51 & -0.14 & 0.62 \\
\hline RQty & -0.49 & 0.56 & 2834 & -0.62 & 0.57 & -0.33 & 0.26 & -1.07 & 0.27 & -0.45 & 0.37 & -0.23 & 0.80 \\
\hline
\end{tabular}

(Source) WDI Database of the World Bank Group (2015), Heritage Foundation (2015), and the author's estimation from Bank scope data for 405 banks across 47 African countries for 2007-2014.

Table 2. Pairwise Correlation Matrix

\begin{tabular}{|c|c|c|c|c|c|c|c|c|c|c|c|c|c|c|}
\hline & z-score & NPLR & FI & LI & CIR & size & CAR & LonR & LonQ & Divers & GDPGPC & Inflation & $\mathrm{CC}$ & RQty \\
\hline z-score & 1.000 & & & & & & & & & & & & & \\
\hline NPLR & $-0.113^{* * * *}$ & 1.000 & & & & & & & & & & & & \\
\hline FI & -0.003 & $-0.164 * * *$ & 1.000 & & & & & & & & & & & \\
\hline LI & $0.218^{* * *}$ & $-0.072^{* *}$ & $-0.052^{* *}$ & 1.000 & & & & & & & & & & \\
\hline CIR & -0.021 & $0.057^{* *}$ & $-0.041^{* *}$ & $-0.356^{* * *}$ & 1.000 & & & & & & & & & \\
\hline size & $0.221^{* * *}$ & 0.018 & $-0.043 * *$ & $0.208^{* * *}$ & $-0.089^{* * *}$ & 1.000 & & & & & & & & \\
\hline CAR & $0.168^{* * *}$ & $-0.089 * * *$ & $-0.089 * * *$ & -0.030 & $0.276 * * *$ & $-0.298 * * *$ & 1.000 & & & & & & & \\
\hline LonR & $0.084^{* * *}$ & 0.0381 & $0.090^{* * *}$ & $-0.041^{* *}$ & $-0.106^{* * *}$ & $0.115^{* * *}$ & $-0.140^{* * * *}$ & 1.000 & & & & & & \\
\hline LonQ & $-0.160^{* * *}$ & $0.281^{* * *}$ & -0.0051 & 0.0254 & -0.009 & $-0.039 * *$ & -0.025 & 0.016 & 1.000 & & & & & \\
\hline Divers & -0.086 & $0.058^{* *}$ & $-0.037^{*}$ & $0.113^{* * *}$ & $-0.064^{* * *}$ & $-0.053^{* *}$ & $-0.093^{* * *}$ & 0.014 & $0.051^{* *}$ & 1.000 & & & & \\
\hline GDPGPC & -0.019 & 0.005 & -0.027 & $0.043^{* *}$ & $0.042^{* *}$ & -0.014 & 0.015 & $-0.048^{* *}$ & -0.003 & $0.034^{*}$ & 1.000 & & & \\
\hline Inflation & -0.029 & 0.029 & $-0.138^{* * *}$ & $-0.035^{*}$ & -0.001 & -0.012 & 0.020 & 0.022 & 0.008 & 0.011 & -0.010 & 1.000 & & \\
\hline $\mathrm{CC}$ & $0.053^{* *}$ & -0.037 & $0.461 * * *$ & 0.010 & -0.014 & $0.039^{* *}$ & $-0.078^{* * *}$ & $0.229^{* * *}$ & -0.056 & -0.017 & 0.011 & $-0.075^{* * *}$ & 1.000 & \\
\hline RQty & $0.059^{* *}$ & $-0.071 * *$ & $0.147^{* * *}$ & $-0.065^{* *}$ & -0.029 & $0.089^{* * *}$ & $-0.114^{* * *}$ & $0.291^{* * *}$ & $-0.037^{*}$ & -0.017 & -0.012 & $-0.132^{* * *}$ & $0.739^{* * *}$ & 1.000 \\
\hline
\end{tabular}

(Source) WDI Database of the World Bank Group, Heritage Foundation and author's estimation from Bank scope data for 405 banks across 47 African countries for 2007-2014. *, **, *** implies statistical significance at $10 \%, 5 \%$, and $1 \%$, respectively. 
loans), followed by the EAC (5.56\%), SADC (4.06\%), AMU (3.72\%) and ECCAS (3.08\%). Financial freedom is also generally low in Africa. The regional average is 45.24. SADC is the most liberalized sub-region, with an average of 50.80, followed by the EAC (49.97), ECOWAS (46.12), ECCAS (36.69), and AMU is the least finically free economic community with an average financial freedom index of 34.18 for the study period. The sub-regional markets display similar disparities in the other variables under study. The correlation matrix in Table 2 also shows that regression variables are normal, with none showing evidence of multicollinearity, since multicollinearity is only implied when two variables have a significant correlation coefficient above 0.7 (Kennedy, 2008).

\section{A. Regression results}

Tables 3 and 4 present the baseline results for equations 1 and 2, respectively using bank z-score as a proxy for bank risk-taking behavior, whereas Tables 5 and 6 present the results for the non-performing loans ratio. Tables 7 and 8 present results of the varying effects of the two proxies for institutional quality (control of corruption and regulatory quality). The diagnostics of the various estimations all prove the fitness of the models used for explaining bank risk-taking in Africa and the sub-regional markets and discussions are based on the results of the model supported by the Hausman specification test.

The results show that the direct effect of financial integration on bank risk-taking behavior in Africa is positive and significant, supporting the integration-fragility perspective. However, the evidence from the sub-regional analyses reveals that the financial integration-fragility view is supported in the EAC but rejected in the AMU banking sector. Notably, whereas increased financial freedom directly increases bank solvency risk in Africa, especially in the EAC, it reduces bank solvency risk in the AMU banking sector. Though Table 5 and 6 show that financial integration directly reduces bank credit risk in Africa, the evidence suggests that its effect on bank solvency risk is less desirable. This suggests that although integration and cross-border banking may be improving banks' credit quality, loss of profitability to new entrants may exert a significant negative effect on overall stability. These findings suggest that for years 2007-2014, which spanned the duration of the recent global financial crisis, increased financial integration in Africa largely promoted bank risk-taking behavior in Africa except for the AMU, which is the least financially free banking system in Africa. These findings are consistent with the findings of Agoraki et al. (2011); Farroukh (2013) and Cubillas and González (2014) for 546 banks from 13 Central and Eastern European economies, the MENA region and 88 developing countries, respectively.

On the direct effect of competition in determining bank risk-taking behavior, the evidence supports the competition-fragility hypothesis. For all samples, the results demonstrate that banks' 
Table 3. Effect of Financial Integration and Competition on Bank Risk-Taking (z-score)

\begin{tabular}{|c|c|c|c|c|c|c|c|c|c|c|c|c|}
\hline \multirow{2}{*}{ z-score } & \multicolumn{2}{|c|}{ AFRICA } & \multicolumn{2}{|c|}{$\mathrm{AMU}$} & \multicolumn{2}{|c|}{ EAC } & \multicolumn{2}{|c|}{ ECCAS } & \multicolumn{2}{|c|}{ ECOWAS } & \multicolumn{2}{|c|}{ SADC } \\
\hline & $\mathrm{FE}$ & $\mathrm{RE}$ & FE & $\mathrm{RE}$ & FE & $\mathrm{RE}$ & $\mathrm{FE}$ & $\mathrm{RE}$ & $\mathrm{FE}$ & $\mathrm{RE}$ & $\mathrm{FE}$ & $\mathrm{RE}$ \\
\hline \multirow[t]{2}{*}{ Constant } & $0.828^{* * *}$ & $0.410^{*}$ & 1.166 & 0.084 & $1.443^{* *}$ & $1.074^{* *}$ & 0.722 & 0.473 & $1.685^{* *}$ & $2.256^{* * *}$ & $1.404^{* * *}$ & 0.315 \\
\hline & $(0.254)$ & $(0.237)$ & (1.010) & $(0.899)$ & $(0.541)$ & $(0.512)$ & $(0.719)$ & $(0.650)$ & $(0.672)$ & $(0.612)$ & $(0.436)$ & $(0.398)$ \\
\hline \multirow[t]{2}{*}{ FI } & -0.001 & 0.001 & $0.010^{* *}$ & $0.011^{* * *}$ & -0.004 & -0.002 & -0.015 & -0.013 & -0.006 & -0.004 & -0.003 & 0.002 \\
\hline & $(0.002)$ & $(0.002)$ & $(0.003)$ & $(0.003)$ & $(0.003)$ & $(0.003)$ & $(0.013)$ & $(0.010)$ & $(0.004)$ & $(0.004)$ & $(0.004)$ & $(0.003)$ \\
\hline \multirow[t]{2}{*}{ LI } & $1.203^{* * *}$ & $1.230^{* * *}$ & 0.627 & 0.501 & $0.841 * * *$ & $0.916^{* * *}$ & 0.170 & 0.186 & $1.605^{* * *}$ & $1.392 * * *$ & $0.767^{* *}$ & $0.887^{* * *}$ \\
\hline & $(0.133)$ & $(0.133)$ & $(0.416)$ & $(0.410)$ & $(0.218)$ & $(0.223)$ & $(0.331)$ & $(0.336)$ & $(0.323)$ & $(0.325)$ & $(0.240)$ & $(0.262)$ \\
\hline \multirow[t]{2}{*}{$\mathrm{LI}^{2}$} & $-1.464^{* * *}$ & $-1.456^{* * *}$ & -0.822 & -0.613 & $-1.226^{* *}$ & $-1.331^{* *}$ & 0.262 & 0.267 & $-2.555^{k * *}$ & $-2.247^{* * *}$ & -0.682 & -0.722 \\
\hline & $(0.257)$ & $(0.257)$ & $(0.720)$ & $(0.711)$ & $(0.456)$ & $(0.466)$ & $(0.564)$ & $(0.576)$ & $(0.594)$ & $(0.598)$ & $(0.446)$ & $(0.488)$ \\
\hline \multirow[t]{2}{*}{ CIR } & $-0.163^{* * *}$ & $-0.163^{* * *}$ & -0.095 & -0.098 & $-0.322 * * *$ & $-0.342^{* * *}$ & $-0.091 * * *$ & $-0.089 * * *$ & $-0.853^{* * *}$ & $-0.986^{* * *}$ & $-0.177 * * *$ & $-0.160 * * *$ \\
\hline & $(0.017)$ & $(0.017)$ & $(0.117)$ & $(0.116)$ & $(0.058)$ & $(0.058)$ & $(0.020)$ & $(0.021)$ & $(0.139)$ & $(0.139)$ & $(0.019)$ & $(0.021)$ \\
\hline \multirow[t]{2}{*}{ Size } & $0.081^{* * *}$ & $0.105^{* * *}$ & 0.079 & $0.152^{* *}$ & $0.058^{*}$ & $0.079 * *$ & $0.080^{* *}$ & $0.091^{* *}$ & 0.054 & $8.54 \mathrm{e}-5$ & 0.041 & $0.108^{* * *}$ \\
\hline & $(0.017)$ & $(0.016)$ & $(0.071)$ & $(0.061)$ & $(0.036)$ & $(0.033)$ & $(0.040)$ & $(0.039)$ & $(0.041)$ & $(0.036)$ & $(0.029)$ & $(0.028)$ \\
\hline \multirow[t]{2}{*}{ CAR } & $6.090 * * *$ & $5.923 * * *$ & $5.341 * * *$ & $5.205^{* * *}$ & $4.459 * * *$ & $4.464^{* * *}$ & $6.046^{* * *}$ & $5.856^{* * *}$ & $8.390 * * *$ & $7.765^{* * *}$ & $7.270 * * *$ & $6.497 * * *$ \\
\hline & $(0.164)$ & $(0.162)$ & $(0.398)$ & $(0.388)$ & $(0.225)$ & $(0.228)$ & $(0.424)$ & $(0.425)$ & $(0.524)$ & $(0.506)$ & $(0.318)$ & $(0.335)$ \\
\hline \multirow[t]{2}{*}{ LoanR } & 0.142 * & 0.125 & $-0.432 * *$ & $-0.513^{* *}$ & -0.147 & -0.122 & $0.448^{* *}$ & $0.440^{* *}$ & 0.064 & 0.274 & 0.088 & 0.030 \\
\hline & $(0.080)$ & $(0.079)$ & $(0.188)$ & $(0.182)$ & $(0.152)$ & $(0.152)$ & $(0.188)$ & $(0.190)$ & $(0.210)$ & $(0.205)$ & $(0.127)$ & $(0.136)$ \\
\hline \multirow[t]{2}{*}{ LonQ } & $-2.451 * * *$ & $-2.508^{* * *}$ & $-1.428 * *$ & $-1.441^{* *}$ & $-1.645^{* *}$ & $-1.586^{* *}$ & $-1.899 * * *$ & $-1.862 * * *$ & $\mathbf{- 3 . 3 8 4} * * *$ & $-3.713^{* * *}$ & $-3.441 * * *$ & $-4.180 * * *$ \\
\hline & $(0.259)$ & $(0.261)$ & $(0.612)$ & $(0.609)$ & $(0.549)$ & $(0.563)$ & $(0.389)$ & $(0.398)$ & $(0.533)$ & $(0.545)$ & $(0.625)$ & $(0.688)$ \\
\hline \multirow[t]{2}{*}{ Divers } & -0.006 & -0.006 & $0.677^{* *}$ & $0.606^{* *}$ & $0.856^{* * *}$ & $0.797 * * *$ & $0.278^{*}$ & 0.243 & -0.009 & -0.008 & -0.039 & -0.046 \\
\hline & $(0.009)$ & $(0.009)$ & $(0.261)$ & $(0.258)$ & $(0.194)$ & $(0.197)$ & $(0.168)$ & $(0.171)$ & $(0.015)$ & $(0.015)$ & $(0.043)$ & $(0.048)$ \\
\hline \multirow[t]{2}{*}{ GDPGPC } & -0.001 & -0.001 & -0.001 & -0.001 & $0.017^{* * *}$ & $0.014^{*}$ & -0.001 & -0.001 & $-0.011^{*}$ & $-0.010^{*}$ & 0.001 & 0.001 \\
\hline & $(0.001)$ & $(0.001)$ & $(0.001)$ & $(0.001)$ & $(0.007)$ & $(0.007)$ & $(0.003)$ & $(0.004)$ & $(0.006)$ & $(0.006)$ & $(0.004)$ & $(0.005)$ \\
\hline \multirow[t]{2}{*}{ Inflation } & $1.91 \mathrm{e}-6$ & $7.90 \mathrm{e}-7$ & $-0.013^{*}$ & $-0.013^{*}$ & $-0.006^{* *}$ & $-0.005^{* *}$ & $0.009^{* *}$ & $0.009^{* *}$ & -0.004 & -0.005 & $3.80 \mathrm{e}-6$ & $1.74 \mathrm{e}-6$ \\
\hline & $(5.86 \mathrm{e}-6)$ & $(5.93 \mathrm{e}-6)$ & $(0.008)$ & $(0.008)$ & $(0.002)$ & $(0.003)$ & $(0.004)$ & $(0.004)$ & $(0.004)$ & $(0.003)$ & $(4.72 \mathrm{e}-6)$ & $(5.23 \mathrm{e}-6)$ \\
\hline Hausman: & 0.000 & 0.000 & 0.353 & 0.353 & 0.000 & 0.000 & 0.030 & 0.030 & 0.000 & 0.000 & 0.000 & 0.000 \\
\hline R-Square & 0.472 & 0.471 & 0.572 & 0.569 & 0.544 & 0.542 & 0.660 & 0.659 & 0.504 & 0.499 & 0.617 & 0.605 \\
\hline F-stat. $/ \mathrm{X}^{2}$ & $150.74^{* * * *}$ & $1630.97 * * *$ & $23.45^{* * *}$ & $263.72^{* * * *}$ & $50.52^{* * *}$ & $528.52^{* * *}$ & $25.93^{* * *}$ & $266.62^{* * *}$ & $42.35^{* * *}$ & $453.16^{* * *}$ & $64.91^{* * *}$ & $558.39 * * *$ \\
\hline Banks & 354 & 354 & 51 & 51 & 80 & 80 & 31 & 31 & 91 & 91 & 80 & 80 \\
\hline Observs. & 2220 & 2220 & 255 & 255 & 557 & 557 & 189 & 189 & 561 & 561 & 534 & 534 \\
\hline
\end{tabular}

Notes: Robust standard errors are reported in parentheses. *, **, *** implies statistical significance at $10 \%, 5 \%$, and $1 \%$, respectively and coefficients in bold are statistically significant. The diagnostic test reported include; (1) the Hausman specification test p-value; (2) the R square value; (3) F-statistic and Wald-chi to indicate the joint significance of the fixed and random effects models; (4) number of observations; and (5) the number of banks used in the estimation.

market power has a significant positive effect on z-scores. Additionally, the evidence on Table 5 and 6 shows that the Lerner Index has a significant negative effect on nonperforming loans in Africa and all sub-regional banking markets, except in the ECCAS sub-region, where the Lerner Index has a significant positive effect on nonperforming loans. These findings suggest that higher monopoly power reduces bank risk-taking behavior and enhances bank stability in Africa's banking systems, supporting Marcus' (1984) competition-fragility hypothesis. However, the quadratic term of the Lerner Index has a significant negative effect on bank z-scores for the full sample, EAC, ECOWAS, and SADC, and a significant positive effect on bank non-performing loans in SADC, and a significant negative effect on nonperforming loans in 
Table 4. Effect of Interaction between Financial Integration and Competition on Bank Risk-Taking (z-score)

\begin{tabular}{|c|c|c|c|c|c|c|c|c|c|c|c|c|}
\hline \multirow{2}{*}{ z-score } & \multicolumn{2}{|c|}{ AFRICA } & \multicolumn{2}{|c|}{$\mathrm{AMU}$} & \multicolumn{2}{|c|}{ EAC } & \multicolumn{2}{|c|}{ ECCAS } & \multicolumn{2}{|c|}{ ECOWAS } & \multicolumn{2}{|c|}{ SADC } \\
\hline & $\mathrm{FE}$ & $\mathrm{RE}$ & $\mathrm{FE}$ & $\mathrm{RE}$ & $\mathrm{FE}$ & $\mathrm{RE}$ & $\mathrm{FE}$ & $\mathrm{RE}$ & $\mathrm{FE}$ & $\mathrm{RE}$ & $\mathrm{FE}$ & $\mathrm{RE}$ \\
\hline \multirow[t]{2}{*}{ Constant } & $0.943^{* * *}$ & $0.491^{* *}$ & 0.955 & -0.114 & $1.463^{* *}$ & $1.117^{* *}$ & 0.406 & 0.242 & $1.829 * *$ & $2.365^{* * *}$ & $1.487^{* * *}$ & 0.362 \\
\hline & $(0.059)$ & $(0.242)$ & (1.015) & $(0.907)$ & $(0.540)$ & $(0.512)$ & $(0.771)$ & $(0.663)$ & $(0.705)$ & $(0.652)$ & $(0.440)$ & $(0.401)$ \\
\hline \multirow[t]{2}{*}{ FI } & $-0.004^{*}$ & -0.002 & $0.018^{* *}$ & $0.018^{* *}$ & $-0.009^{* *}$ & $-0.007^{*}$ & -0.003 & -0.002 & -0.009 & -0.006 & -0.006 & $3.57 \mathrm{e}-4$ \\
\hline & $(0.002)$ & $(0.002)$ & $(0.006)$ & $(0.006)$ & $(0.004)$ & $(0.004)$ & $(0.016)$ & $(0.012)$ & $(0.006)$ & $(0.006)$ & $(0.005)$ & $(0.004)$ \\
\hline \multirow[t]{2}{*}{ LI } & $0.738^{* *}$ & $0.881^{* * *}$ & $1.156^{* *}$ & $1.028^{*}$ & -0.039 & 0.005 & 0.848 & $1.113^{*}$ & $1.177^{*}$ & 1.069 & 0.334 & 0.604 \\
\hline & $(0.248)$ & $(0.246)$ & $(0.535)$ & $(0.532)$ & $(0.522)$ & $(0.533)$ & $(0.688)$ & $(0.653)$ & $(0.706)$ & $(0.708)$ & $(0.400)$ & $(0.428)$ \\
\hline \multirow[t]{2}{*}{$\mathrm{LI}^{2}$} & $-1.458^{* * *}$ & $-1.450^{* * *}$ & -0.630 & -0.443 & $-1.180^{* *}$ & $-1.282^{* *}$ & 0.155 & 0.111 & $-2.570 * * *$ & $-2.260^{* * *}$ & $-0.759^{*}$ & -0.773 \\
\hline & $(0.256)$ & $(0.257)$ & $(0.727)$ & $(0.717)$ & $(0.456)$ & $(0.465)$ & $(0.572)$ & $(0.578)$ & $(0.595)$ & (0.599) & $(0.450)$ & $(0.491)$ \\
\hline \multirow[t]{2}{*}{$\mathrm{LI} * \mathrm{FI}$} & $0.010^{* *}$ & $0.007^{*}$ & -0.020 & -0.019 & $0.019^{*}$ & $0.020^{*}$ & -0.015 & $-0.020^{*}$ & 0.009 & 0.007 & 0.009 & 0.006 \\
\hline & $(0.005)$ & $(0.004)$ & $(0.013)$ & $(0.012)$ & $(0.010)$ & $(0.011)$ & $(0.013)$ & $(0.012)$ & $(0.013)$ & $(0.013)$ & $(0.007)$ & $(0.007)$ \\
\hline \multirow[t]{2}{*}{ CIR } & $-0.162^{* * *}$ & $-0.163^{* * *}$ & -0.077 & -0.082 & $-0.276^{* * *}$ & $-0.295^{* * *}$ & $-0.089^{* * *}$ & $-0.086^{* * *}$ & $-0.858^{* * *}$ & $-0.989^{* * *}$ & $-0.177^{* * *}$ & $-0.160^{* * *}$ \\
\hline & $(0.017)$ & $(0.017)$ & $(0.118)$ & $(0.116)$ & $(0.062)$ & $(0.063)$ & $(0.020)$ & $(0.021)$ & $(0.139)$ & (0.139) & $(0.019)$ & $(0.021)$ \\
\hline \multirow[t]{2}{*}{ Size } & $0.083^{* * *}$ & $0.107^{* * * *}$ & 0.076 & $0.148^{* *}$ & $0.065^{*}$ & $0.085^{* *}$ & $0.072 *$ & $0.078^{* *}$ & 0.054 & $6.16 \mathrm{e}-5$ & 0.046 & $0.111^{* * *}$ \\
\hline & $(0.017)$ & $(0.016)$ & $(0.071)$ & $(0.061)$ & $(0.036)$ & (0.033) & $(0.040)$ & $(0.040)$ & $(0.041)$ & $(0.036)$ & $(0.030)$ & $(0.028)$ \\
\hline \multirow[t]{2}{*}{ CAR } & $6.104^{* * *}$ & $5.930^{* * *}$ & $5.237^{* * *}$ & $5.115^{* * *}$ & $4.510^{* * * *}$ & $4.513^{* * *}$ & $6.039^{* * * *}$ & $5.881^{* * *}$ & $8.433^{* * *}$ & $7.796^{* * *}$ & $7.328^{* * *}$ & $6.540^{* * *}$ \\
\hline & $(0.164)$ & $(0.162)$ & $(0.402)$ & $(0.391)$ & $(0.226)$ & $(0.229)$ & $(0.424)$ & $(0.421)$ & $(0.528)$ & (0.509) & $(0.321)$ & $(0.337)$ \\
\hline \multirow[t]{2}{*}{ LoanR } & $0.153^{*}$ & $0.133^{*}$ & $-0.411^{* *}$ & $-0.490^{* *}$ & -0.062 & -0.036 & $0.422^{* *}$ & $0.394^{* *}$ & 0.068 & 0.277 & 0.096 & 0.035 \\
\hline & $(0.081)$ & $(0.079)$ & $(0.188)$ & $(0.182)$ & $(0.158)$ & $(0.158)$ & (0.189) & $(0.191)$ & $(0.210)$ & $(0.205)$ & $(0.127)$ & $(0.136)$ \\
\hline \multirow[t]{2}{*}{ LonQ } & $-2.458^{* * *}$ & $-2.513^{* \dot{*} *}$ & $-1.405^{\star *}$ & $-1.429^{* *}$ & $-1.658^{* * *}$ & $-1.597^{* *}$ & $-1.887^{* * * *}$ & $-1.820 * * *$ & $-3.382^{* * *}$ & $-3.707^{* * *}$ & $-3.472^{* * *}$ & $-4.192^{* * * *}$ \\
\hline & $(0.259)$ & $(0.261)$ & $(0.610)$ & $(0.607)$ & $(0.548)$ & $(0.561)$ & $(0.389)$ & $(0.394)$ & $(0.534)$ & $(0.545)$ & $(0.625)$ & $(0.687)$ \\
\hline \multirow[t]{2}{*}{ Divers } & -0.006 & -0.006 & $0.669 * *$ & $0.601 * *$ & $0.873^{* * *}$ & $0.815^{* * *}$ & 0.232 & 0.195 & -0.009 & -0.008 & -0.047 & -0.051 \\
\hline & $(0.009)$ & $(0.009)$ & $(0.260)$ & $(0.257)$ & $(0.193)$ & $(0.196)$ & $(0.173)$ & $(0.172)$ & $(0.015)$ & $(0.015)$ & $(0.043)$ & $(0.048)$ \\
\hline \multirow[t]{2}{*}{ GDPGPC } & -0.001 & -0.001 & -0.001 & -0.001 & $0.017^{* *}$ & $0.013^{*}$ & -0.001 & -0.001 & $-0.011^{*}$ & $-0.010^{*}$ & 0.001 & 0.001 \\
\hline & $(0.001)$ & $(0.001)$ & $(0.001)$ & $(0.001)$ & $(0.007)$ & $(0.007)$ & $(0.003)$ & $(0.004)$ & $(0.006)$ & $(0.006)$ & $(0.004)$ & $(0.005)$ \\
\hline \multirow[t]{2}{*}{ Inflation } & $1.73 \mathrm{e}-6$ & $6.03 \mathrm{e}-7$ & $-0.013^{*}$ & $-0.013^{*}$ & $-0.006^{* *}$ & $-0.005^{* *}$ & $0.009^{* *}$ & $0.010^{* *}$ & -0.003 & -0.005 & $3.52 \mathrm{e}-6$ & $1.54 \mathrm{e}-6$ \\
\hline & $(5.85 \mathrm{e}-6)$ & $(5.92 \mathrm{e}-6)$ & $(0.007)$ & $(0.007)$ & $(0.002)$ & $(0.003)$ & $(0.004)$ & $(0.004)$ & $(0.004)$ & $(0.004)$ & $(4.72 \mathrm{e}-6)$ & $(5.22 \mathrm{e}-6)$ \\
\hline Hausman: & 0.000 & 0.000 & 0.370 & 0.370 & 0.000 & 0.000 & 0.085 & 0.085 & 0.000 & 0.000 & 0.000 & 0.000 \\
\hline R-square & 0.473 & 0.472 & 0.577 & 0.574 & 0.547 & 0.546 & 0.663 & 0.662 & 0.504 & 0.500 & 0.619 & 0.607 \\
\hline F-stat. $/ \mathrm{X}^{2}$ & $138.89^{* * * *}$ & $1635.18^{* * *}$ & $21.86^{* * * *}$ & $268.17^{* * *}$ & $46.84^{* * *}$ & $536.20^{* * *}$ & $23.92^{* * *}$ & $275.19^{* * * k}$ & $38.81^{* * * *}$ & $453.65^{\star * * *}$ & $\mathbf{5 9 . 7 7 ^ { * * * * }}$ & $561.40^{* * *}$ \\
\hline Banks & 354 & 354 & 51 & 51 & 80 & 80 & 31 & 31 & 91 & 91 & 80 & 80 \\
\hline Observs. & 2220 & 2220 & 255 & 255 & 557 & 557 & 189 & 189 & 561 & 561 & 534 & 534 \\
\hline
\end{tabular}

the ECCAS. These findings are consistent with the Martinez-Mierra and Repullo (MMR) (2010) theory, suggesting a nonlinear U-shaped relationship between bank competition and risk-taking behavior. Therefore, in African banking systems, increases in competition or a loss of market power due to increased financial integration promotes bank risk-taking behavior up to a certain threshold, beyond which further increases in bank competition will reduce bank risk-taking behavior.

Accounting for the indirect effect of financial integration on bank risk-taking through competitive channel, Tables 4,7 and 8 demonstrate a significant positive correlation between 
Table 5. Effect of Financial Integration and Competition on Bank Risk-Taking (Non-Performing Loans Ratio)

\begin{tabular}{|c|c|c|c|c|c|c|c|c|c|c|c|c|}
\hline \multirow{2}{*}{ NPLR } & \multicolumn{2}{|c|}{ AFRICA } & \multicolumn{2}{|c|}{ AMU } & \multicolumn{2}{|c|}{ EAC } & \multicolumn{2}{|c|}{ ECCAS } & \multicolumn{2}{|c|}{ ECOWAS } & \multicolumn{2}{|c|}{ SADC } \\
\hline & $\mathrm{FE}$ & $\mathrm{RE}$ & FE & $\mathrm{RE}$ & FE & $\mathrm{RE}$ & FE & $\mathrm{RE}$ & $\mathrm{FE}$ & $\mathrm{RE}$ & $\mathrm{FE}$ & $\mathrm{RE}$ \\
\hline \multirow[t]{2}{*}{ Constant } & $-6.141^{* * * *}$ & $-3.983^{* * *}$ & 5.152 & $4.575^{*}$ & -1.877 & -0.818 & $-21.400^{* *}$ & $-10.330^{* * *}$ & $-5.374^{* * *}$ & -1.200 & $-10.503^{* * *}$ & $-\mathbf{5 . 5 9 0} * * *$ \\
\hline & (1.005) & $(0.554)$ & (5.277) & (2.578) & (2.107) & (1.462) & (6.756) & (2.170) & (2.716) & $(1.247)$ & (2.147) & (1.103) \\
\hline \multirow[t]{2}{*}{ FI } & 0.004 & $-0.009^{* *}$ & -0.010 & $-0.032^{* *}$ & $-0.023 * *$ & $-0.034^{* * *}$ & -0.003 & $0.054^{* *}$ & $0.052^{* * *}$ & 0.011 & $0.051^{* * *}$ & -0.005 \\
\hline & $(0.006)$ & $(0.004)$ & $(0.014)$ & $(0.011)$ & $(0.010)$ & (0.009) & $(0.133)$ & $(0.022)$ & $(0.013)$ & $(0.008)$ & $(0.015)$ & $(0.006)$ \\
\hline \multirow[t]{2}{*}{ LI } & -0.705 & $-0.723^{* *}$ & -2.157 & -2.760 & -0.042 & -0.258 & 2.622 & $4.760^{* *}$ & -1.409 & $-1.630^{*}$ & $-2.679^{* *}$ & $-1.640^{*}$ \\
\hline & $(0.485)$ & $(0.445)$ & (2.122) & (1.912) & (0.904) & $(0.860)$ & (2.317) & (2.002) & (1.069) & $(0.918)$ & (1.08) & $(0.956)$ \\
\hline \multirow[t]{2}{*}{$\mathrm{LI}^{2}$} & 0.872 & 0.592 & 2.841 & 2.056 & -0.586 & -0.959 & -2.134 & $-5.803^{* *}$ & 1.237 & 1.694 & $3.376^{* *}$ & $2.706 *$ \\
\hline & $(0.953)$ & $(0.858)$ & (2.658) & (2.495) & (1.988) & (1.885) & (3.936) & (3.549) & (1.934) & (1.667) & (1.719) & (1.600) \\
\hline \multirow[t]{2}{*}{ CIR } & 0.001 & -0.024 & 0.012 & -0.331 & $-0.926 * * *$ & $-0.781^{* * *}$ & $0.298^{* *}$ & $0.255^{*}$ & 0.113 & $-0.863^{*}$ & 0.221 & 0.587 \\
\hline & $(0.078)$ & $(0.075)$ & (1.217) & $(0.959)$ & $(0.224)$ & $(0.207)$ & $(0.129)$ & $(0.134)$ & $(0.691)$ & $(0.507)$ & $(0.398)$ & $(0.367)$ \\
\hline \multirow[t]{2}{*}{ Size } & $0.226^{* * *}$ & $0.095^{* *}$ & -0.299 & -0.181 & 0.077 & -0.023 & $1.222^{* * * *}$ & 0.159 & -0.064 & $-0.137^{* *}$ & $0.337^{* *}$ & $0.121^{*}$ \\
\hline & $(0.067)$ & $(0.035)$ & $(0.330)$ & $(0.147)$ & (9.133) & $(0.086)$ & $(0.312)$ & $(0.169)$ & $(0.153)$ & $(0.063)$ & $(0.140)$ & $(0.070)$ \\
\hline \multirow[t]{2}{*}{ CAR } & $1.176^{*}$ & 0.737 & -2.792 & -3.351 ** & $-2.139^{*}$ & -1.566 & 5.077 & 2.863 & $3.681^{* *}$ & 0.960 & 0.087 & 0.539 \\
\hline & $(0.691)$ & $(0.589)$ & (2.528) & (1.726) & (1.157) & (1.048) & $(4.061)$ & (2.961) & (1.515) & (1.095) & (1.258) & (1.132) \\
\hline \multirow[t]{2}{*}{ LoanR } & $-0.669^{* *}$ & -0.109 & $-2.937 * * *$ & $-1.922^{* *}$ & $-1.038^{*}$ & -0.391 & -1.022 & 1.594 & 0.060 & -0.089 & -0.026 & 0.282 \\
\hline & $(0.299)$ & $(0.241)$ & $(0.881)$ & $(0.681)$ & $(0.582)$ & $(0.515)$ & (1.533) & (1.164) & $(0.621)$ & $(0.463)$ & $(0.507)$ & $(0.418)$ \\
\hline \multirow[t]{2}{*}{ LonQ } & $11.470^{* * *}$ & $12.271^{* * * *}$ & 8.235 & $10.251^{*}$ & $16.922^{* * *}$ & $17.198^{* * * *}$ & 11.093 & $12.048^{*}$ & $3.292^{*}$ & $5.856^{* * *}$ & $14.377^{* * *}$ & $15.587^{* * *}$ \\
\hline & (1.110) & (1.061) & (6.341) & $(6.265)$ & (2.091) & (2.015) & (6.876) & (7.048) & (1.834) & (1.792) & $(2.262)$ & (2.147) \\
\hline \multirow[t]{2}{*}{ Divers } & 0.003 & 0.006 & -1.209 & $-2.499^{*}$ & 1.136 & $1.390^{* * *}$ & 0.263 & $2.873^{* *}$ & 0.951 & $1.000^{*}$ & 0.073 & 0.189 \\
\hline & $(0.042)$ & $(0.042)$ & (1.554) & (1.358) & $(0.761)$ & $(0.677)$ & (1.849) & (1.236) & $(0.604)$ & $(0.561)$ & $(0.213)$ & $(0.212)$ \\
\hline \multirow[t]{2}{*}{ GDPGPC } & -0.003 & -0.001 & 0.003 & 0.007 & -0.036 & -0.020 & -0.005 & $-0.056^{* * *}$ & $0.040^{* *}$ & $0.032^{* *}$ & -0.001 & -0.001 \\
\hline & $(0.005)$ & $(0.005)$ & $(0.005)$ & $(0.005)$ & $(0.024)$ & $(0.022)$ & $(0.026)$ & $(0.026)$ & $(0.017)$ & $(0.016)$ & $(0.016)$ & $(0.016)$ \\
\hline \multirow[t]{2}{*}{ Inflation } & $4.55 \mathrm{e}-5^{* *}$ & $4.5 \mathrm{e}-5^{* *}$ & -0.016 & -0.001 & -0.003 & -0.005 & 0.037 & -0.055 & $0.021^{*}$ & -0.001 & $4.46 \mathrm{e}-5^{* *}$ & $4.87 \mathrm{e}-5^{* * *}$ \\
\hline & $(1.74 \mathrm{e}-5)$ & $(1.7 \mathrm{e}-5)$ & $(0.040)$ & $(0.040)$ & (0.009) & $(0.008)$ & $(0.042)$ & $(0.038)$ & $(0.011)$ & $(0.010)$ & $(1.59 \mathrm{e}-5)$ & $(1.61 \mathrm{e}-5)$ \\
\hline Hausman & 0.000 & 0.000 & 0.068 & 0.068 & 0.066 & 0.066 & 0.000 & 0.000 & 0.000 & 0.000 & 0.000 & 0.000 \\
\hline R-Square & 0.093 & 0.085 & 0.217 & 0.173 & 0.303 & 0.296 & 0.384 & 0.243 & 0.115 & 0.063 & 0.220 & 0.176 \\
\hline F-stat./ $\mathrm{X}^{2}$ & $12.05^{* * *}$ & $163.30^{* * * *}$ & $2.37^{* * *}$ & $33.92^{* * *}$ & $15.11^{* * *}$ & $174.73^{* * *}$ & $4.25^{* * *}$ & $42.04^{* * *}$ & $3.63^{* * *}$ & $34.36^{* * *}$ & $8.25^{* \star *}$ & $96.46^{* * * k}$ \\
\hline Banks & 287 & 354 & 27 & 27 & 76 & 76 & 20 & 20 & 74 & 74 & 71 & 71 \\
\hline Observs. & 1595 & 2220 & 132 & 132 & 470 & 470 & 106 & 106 & 392 & 392 & 404 & 404 \\
\hline
\end{tabular}

Notes: Robust standard errors are reported in parentheses. *,**,*** implies statistical significance at $10 \%, 5 \%$, and $1 \%$, respectively and coefficients in bold are statistically significant. The diagnostic test reported include; (1) the Hausman specification test p-value; (2) the R square value; (3) F-statistic and Wald-chi to indicate the joint significance of the fixed and random effects models; (4) number of observations; and (5) the number of banks used in the estimation.

the interaction term in Equation 2 and bank z-scores for the full sample and EAC sample, and a significant negative effect in the ECCAS. Additionally, the interaction term has a significant positive effect on bank non-performing loans in the full sample and AMU banking sectors but a negative and insignificant effect in the EAC banking sector (Table 6). This suggests that in concentrated banking markets, increased financial freedom and competition changes promote bank stability, despite rising nonperforming loans.

These findings suggest that competition changes from increased financial integration enhance bank stability in Africa. The positive effect on non-performing loans could be due to the global financial crisis, which led to significant loan losses for most banks globally. However, the 
Table 6. Effect of Interaction between Financial Integration and Competition on Bank Risk-Taking (NPL Ratio)

\begin{tabular}{|c|c|c|c|c|c|c|c|c|c|c|c|c|}
\hline \multirow{2}{*}{ NPLR } & \multicolumn{2}{|c|}{ AFRICA } & \multicolumn{2}{|c|}{$\mathrm{AMU}$} & \multicolumn{2}{|c|}{ EAC } & \multicolumn{2}{|c|}{ ECCAS } & \multicolumn{2}{|c|}{ ECOWAS } & \multicolumn{2}{|c|}{ SADC } \\
\hline & $\mathrm{FE}$ & $\mathrm{RE}$ & $\mathrm{FE}$ & $\mathrm{RE}$ & $\mathrm{FE}$ & $\mathrm{RE}$ & $\mathrm{FE}$ & $\mathrm{RE}$ & $\mathrm{FE}$ & $\mathrm{RE}$ & $\mathrm{FE}$ & $\mathrm{RE}$ \\
\hline \multirow[t]{2}{*}{ Constant } & $-5.479^{* * * *}$ & $-3.500^{* * *}$ & $10.768^{*}$ & $7.716^{* * *}$ & -2.106 & -1.071 & $-16.055^{* *}$ & $-9.962^{* * * *}$ & $-5.247^{*}$ & -1.323 & $-10.190^{* * * *}$ & $-5.336^{* * *}$ \\
\hline & (1.024) & $(0.582)$ & (5.789) & (2.773) & (2.121) & (1.484) & (6.697) & $(2.666)$ & $(2.805)$ & (1.396) & (2.177) & (1.128) \\
\hline \multirow[t]{2}{*}{ FI } & -0.012 & $-0.020 * * *$ & $-0.079^{* *}$ & $-0.095 * * *$ & -0.015 & $-0.025^{* *}$ & -0.199 & 0.034 & $0.049^{* *}$ & 0.013 & $0.041^{* *}$ & -0.011 \\
\hline & $(0.008)$ & $(0.006)$ & $(0.034)$ & $(0.026)$ & $(0.013)$ & $(0.012)$ & $(0.144)$ & $(0.034)$ & (0.019) & $(0.013)$ & $(0.019)$ & $(0.008)$ \\
\hline \multirow[t]{2}{*}{ LI } & $-3.286^{* * *}$ & $-2.694^{* * *}$ & $-8.026^{* *}$ & $-8.480^{* * *}$ & 1.977 & 1.724 & $-11.274^{* *}$ & 2.142 & -1.756 & -1.378 & $-3.866^{* *}$ & $-2.650^{*}$ \\
\hline & $(0.961)$ & $(0.842)$ & (3.416) & $(2.850)$ & $(2.310)$ & $(2.207)$ & $(5.252)$ & (3.890) & (2.148) & (1.712) & (1.724) & (1.511) \\
\hline \multirow[t]{2}{*}{$\mathrm{LI}^{2}$} & 0.849 & 0.677 & 1.886 & 1.177 & -0.663 & -0.977 & -3.490 & -4.915 & 1.224 & 1.712 & $3.110^{*}$ & 2.510 \\
\hline & $(0.950)$ & $(0.857)$ & (2.644) & $(2.458)$ & (1.990) & (1.886) & $(3.781)$ & (3.586) & (1.938) & $(1.672)$ & (1.746) & (1.608) \\
\hline \multirow[t]{2}{*}{$\mathrm{LI}^{*} \mathrm{FI}$} & $0.055^{* *}$ & $0.041^{* *}$ & $0.153^{* *}$ & $0.154^{* *}$ & -0.041 & -0.041 & $0.352^{* *}$ & 0.051 & 0.007 & -0.005 & 0.026 & 0.022 \\
\hline & $(0.018)$ & $(0.015)$ & $(0.071)$ & $(0.058)$ & $(0.043)$ & $(0.042)$ & $(0.121)$ & $(0.076)$ & $(0.039)$ & $(0.031)$ & $(0.030)$ & $(0.025)$ \\
\hline \multirow[t]{2}{*}{ CIR } & -0.005 & -0.029 & -0.982 & -1.157 & $-0.990^{* * *}$ & $-0.842 * * *$ & $0.266^{* *}$ & $0.252^{*}$ & 0.105 & $-0.858^{*}$ & 0.168 & 0.556 \\
\hline & $(0.078)$ & $(0.075)$ & (1.279) & $(0.985)$ & $(0.234)$ & $(0.216)$ & $(0.124)$ & $(0.131)$ & $(0.693)$ & $(0.509)$ & $(0.403)$ & $(0.371)$ \\
\hline \multirow[t]{2}{*}{ Size } & $0.231^{* * * *}$ & $0.099 * *$ & -0.452 & -0.179 & 0.071 & -0.028 & $1.384^{* * * *}$ & 0.216 & -0.064 & $-0.135^{* * *}$ & $0.351^{* * *}$ & $0.124^{*}$ \\
\hline & $(0.068)$ & $(0.035)$ & $(0.331)$ & $(0.143)$ & $(0.133)$ & $(0.086)$ & $(0.302)$ & $(0.178)$ & $(0.153)$ & $(0.065)$ & $(0.141)$ & $(0.069)$ \\
\hline \multirow[t]{2}{*}{ CAR } & $1.156^{*}$ & 0.692 & -3.049 & $-3.569^{* *}$ & $-2.260^{* * *}$ & -1.637 & 5.923 & 2.725 & $3.706^{* *}$ & 0.979 & 0.061 & 0.436 \\
\hline & $(0.689)$ & $(0.589)$ & (2.483) & (1.683) & (1.164) & (1.051) & (3.883) & (3.069) & (1.523) & (1.098) & (1.258) & (1.138) \\
\hline \multirow[t]{2}{*}{ LoanR } & $-0.572^{*}$ & -0.083 & $-3.235^{* * *}$ & $-2.324^{* * *}$ & $-1.107^{*}$ & -0.445 & -0.186 & 1.374 & 0.060 & -0.093 & 0.031 & 0.310 \\
\hline & $(0.300)$ & $(0.241)$ & $(0.875)$ & $(0.681)$ & $(0.587)$ & $(0.518)$ & $(1.490)$ & (1.205) & $(0.622)$ & $(0.464)$ & $(0.511)$ & $(0.417)$ \\
\hline \multirow[t]{2}{*}{ LonQ } & $11.527^{* * * *}$ & $12.318^{* * * *}$ & 9.073 & $10.580^{*}$ & $16.981^{* * * *}$ & $17.290^{* * *}$ & $17.717^{* * *}$ & $13.583^{*}$ & $3.315^{*}$ & $5.805^{* * *}$ & $14.423^{\star * * *}$ & $15.617^{* * * *}$ \\
\hline & (1.106) & (1.059) & $(6.232)$ & (6.124) & (2.093) & (2.017) & (6.938) & (7.182) & $(1.841)$ & (1.799) & $(2.263)$ & (2.151) \\
\hline \multirow[t]{2}{*}{ Divers } & 0.004 & 0.008 & -0.898 & $-2.319^{*}$ & 1.168 & $1.421^{* *}$ & 0.173 & $2.453^{* *}$ & 0.953 & $0.996^{*}$ & 0.048 & 0.182 \\
\hline & $(0.042)$ & $(0.042)$ & (1.531) & (1.327) & $(0.762)$ & $(0.678)$ & (1.763) & (1.252) & $(0.605)$ & $(0.562)$ & $(0.215)$ & $(0.214)$ \\
\hline \multirow[t]{2}{*}{ GDPGPC } & -0.004 & -0.002 & 0.004 & 0.007 & -0.035 & -0.020 & 0.009 & $-0.052^{* *}$ & $0.040^{* *}$ & $0.033^{* * *}$ & -0.003 & -0.003 \\
\hline & $(0.005)$ & $(0.005)$ & $(0.005)$ & $(0.005)$ & $(0.024)$ & $(0.022)$ & $(0.025)$ & $(0.026)$ & $(0.017)$ & $(0.017)$ & $(0.016)$ & $(0.016)$ \\
\hline \multirow[t]{2}{*}{ Inflation } & $4.6 e-5^{* *}$ & $4.36 \mathrm{e}-5^{* *}$ & 0.002 & 0.008 & -0.004 & -0.006 & 0.031 & -0.056 & $0.021^{*}$ & -0.002 & $4.42 \mathrm{e}-5^{* *}$ & $4.77 e-5^{* * *}$ \\
\hline & $(1.73 e-5)$ & $(1.7 \mathrm{e}-5)$ & $(0.040)$ & $(0.039)$ & $(0.009)$ & $(0.008)$ & $(0.040)$ & $(0.039)$ & $(0.012)$ & $(0.010)$ & $(1.59 \mathrm{e}-5)$ & $(1.62 \mathrm{e}-5)$ \\
\hline Hausman & 0.000 & 0.000 & 0.124 & 0.124 & 0.076 & 0.076 & 0.000 & 0.000 & 0.000 & 0.000 & 0.000 & 0.000 \\
\hline R-Square & 0.099 & 0.092 & 0.255 & 0.220 & 0.304 & 0.297 & 0.447 & 0.274 & 0.115 & 0.063 & 0.222 & 0.180 \\
\hline F-stat./X & $11.92^{* k * k}$ & $171.44^{* * *}$ & $2.65^{* *}$ & $42.81^{* * *}$ & $13.92^{* * *}$ & $175.61^{* * *}$ & $4.99^{* k *}$ & $40.88^{* k * *}$ & $3.32^{* k *}$ & $34.26^{* * * *}$ & $7.62^{* * * *}$ & $97.93^{\star * * k}$ \\
\hline Banks & 287 & 287 & 27 & 27 & 76 & 76 & 20 & 20 & 74 & 74 & 71 & 71 \\
\hline Observs. & 1595 & 1595 & 132 & 132 & 470 & 470 & 106 & 106 & 392 & 392 & 404 & 404 \\
\hline
\end{tabular}

Notes: Robust standard errors are reported in parentheses. *, **, *** implies statistical significance at $10 \%, 5 \%$, and $1 \%$, respectively and coefficients in bold are statistically significant. The diagnostic test reported include; (1) the Hausman specification test p-value; (2) the R square value; (3) F-statistic and Wald-chi to indicate the joint significance of the fixed and random effects models; (4) number of observations; and (5) the number of banks used in the estimation. The interaction term (LI*FI) indicates the effect of the interaction between competition and financial integration for each sample.

two results could mean that though the global financial crisis, a product of banking integration, resulted in higher bank non-performing loans, regulatory and other benefits of financial integration led to significant stability gains in the entire region. Notably, Farroukh (2013) suggest that the positive effect on non-performing loans, despite a significant negative effect on insolvency risk, could be due to expansion of opportunities for increased lending and associated risk in these regions. In addition, the findings support the perspective that deregulation-induced changes in bank competition promote bank stability even with rising loan losses. According to this view, fear of market share and profitability losses from a more deregulated and competitive banking 
system, and a downward movement of intermediation spreads, forces banks to pursue efficiency.

Regarding the effects of institutional quality on bank risk-taking, Table 7 shows that control of corruption has a significant positive effect on bank z-scores in the SADC banking sector but a significant negative effect in the AMU banking system. This means that a reduction in corruption reduces bank insolvency risk in the SADC region but increases insolvency risk in the AMU banking sector. In Table 8, regulatory quality is found to have a significant positive effect on bank non-performing loans in the full sample, especially in ECOWAS and SADC banking markets. These findings show that institutional quality plays a significant role in determining bank risk-taking behavior in Africa, especially in the ECOWAS and SADC sub-regional banking markets.

The results of the control variables generally mirror the literature and demonstrate that bank management quality, capitalization, and loan quality all reduce bank insolvency and credit risks in Africa and all sub-regional banking markets. Bank cost-to-income ratio in all samples has a significant negative effect on bank z-score except in the AMU where the negative effect was insignificant. This shows that higher operating costs or lower management quality increases bank risk-taking behavior in Africa. Similarly, loan quality, measured as loan loss provisions to total loans negatively impacts bank z-scores and positively impacts non-performing loans in almost all samples. This suggest that poor loan quality increases bank risk-taking behavior. Furthermore, bank capitalization is found to exert a significant positive effect on bank z-scores in all samples. However, capitalization was found to promote bank nonperforming loans in the EAC banking sector, suggesting that highly capitalized banks in the EAC undertook poor lending activities within the 2007-2014 period. The coefficient of bank size on z-score is positive and significant in the full sample, EAC, ECCAS and SADC, whereas its effect on nonperforming loans is positive and significant in the full sample and SADC but negative and significant in the ECOWAS banking sector. This suggests that though bank size reduces bank insolvency risk in Africa, it also promotes higher credit risk-taking among banks, especially in the SADC banking sector. However, for the ECOWAS banking sector, size helps reduce credit risk as well as insolvency risk. With respect to loan ratio, the coefficients are positive and significant for z-score in the full sample and ECCAS but negative and significant in the AMU sample. Table 5 also shows that loan ratio has a negative and significant effect on the NPL ratio in the AMU and EAC samples, suggesting that a rise in bank lending activities does not lead to greater fragility in Africa. Diversification was found to reduce bank insolvency risk in AMU and EAC banking sectors. However, Tables 5 and 6 show that diversification increases bank credit risk in ECCAS and ECOWAS banking markets. Per capita GDP growth rate reduces bank insolvency risk in the EAC and reduces credit risk in the ECCAS region but increases both credit and insolvency risk in the ECOWAS banking sector. Inflation was also found to significantly increase bank insolvency (Table 3) in the AMU, EAC, and in the full sample 
and SADC banking sector (Tables 5, 6, 7, and 8), and credit risks (Table 5) in the full sample and SADC banking sectors (Tables 5 and 6). The effect of inflation on bank z-score was positive in the ECCAS sample (Table 3).

Table 7. Effect of Control of Corruption on the Relationship between Financial Integration, Competition and Bank Risk-Taking

\begin{tabular}{|c|c|c|c|c|c|c|c|c|c|c|c|c|}
\hline \multirow{2}{*}{ z-score } & \multicolumn{2}{|c|}{ AFRICA } & \multicolumn{2}{|c|}{$\mathrm{AMU}$} & \multicolumn{2}{|c|}{ EAC } & \multicolumn{2}{|c|}{ ECCAS } & \multicolumn{2}{|c|}{ ECOWAS } & \multicolumn{2}{|c|}{ SADC } \\
\hline & $\mathrm{FE}$ & $\mathrm{RE}$ & $\mathrm{FE}$ & $\mathrm{RE}$ & $\mathrm{FE}$ & $\mathrm{RE}$ & $\mathrm{FE}$ & $\mathrm{RE}$ & $\mathrm{FE}$ & $\mathrm{RE}$ & $\mathrm{FE}$ & $\mathrm{RE}$ \\
\hline \multirow[t]{2}{*}{ Constant } & $0.961^{* * *}$ & $0.492^{* *}$ & 1.245 & 0.027 & $1.460^{* *}$ & $1.161^{* * *}$ & 0.269 & 0.118 & $1.895^{* *}$ & $2.351^{* * *}$ & $1.428^{* * *}$ & 0.557 \\
\hline & $(0.259)$ & $(0.242)$ & (1.023) & $(0.907)$ & $(0.542)$ & $(0.513)$ & $(0.810)$ & $(0.706)$ & $(0.707)$ & $(0.654)$ & $(0.442)$ & $(0.401)$ \\
\hline \multirow[t]{2}{*}{ FI } & -0.003 & -0.002 & $0.018^{* *}$ & $0.019^{* * *}$ & $-0.009 * *$ & $-0.007^{*}$ & -0.003 & -0.001 & -0.009 & -0.006 & -0.006 & -0.004 \\
\hline & $(0.002)$ & $(0.002)$ & $(0.006)$ & $(0.006)$ & $(0.004)$ & $(0.004)$ & $(0.017)$ & $(0.012)$ & $(0.006)$ & $(0.006)$ & $(0.005)$ & $(0.004)$ \\
\hline \multirow[t]{2}{*}{ LI } & $0.733^{* *}$ & $0.881 * * *$ & $1.112^{* *}$ & $0.984^{*}$ & -0.032 & -0.103 & 0.828 & $1.091^{*}$ & $1.170^{*}$ & 1.069 & 0.310 & 0.465 \\
\hline & $(0.133)$ & $(0.246)$ & $(0.533)$ & $(0.529)$ & $(0.530)$ & $(0.540)$ & $(0.690)$ & $(0.655)$ & $(0.706)$ & $(0.708)$ & $(0.399)$ & $(0.426)$ \\
\hline \multirow[t]{2}{*}{$\mathrm{LI}^{2}$} & $-1.449^{* * *}$ & $-1.452 * * *$ & -0.524 & -0.355 & $-1.183^{* *}$ & $-1.221^{* *}$ & 0.138 & 0.097 & $-2.572 * * *$ & $-2.264^{* * *}$ & $-0.764^{*}$ & $-0.807^{*}$ \\
\hline & $(0.257)$ & $(0.257)$ & $(0.726)$ & $(0.714)$ & $(0.459)$ & $(0.467)$ & $(0.574)$ & $(0.580)$ & $(0.594)$ & $(0.599)$ & $(0.449)$ & $(0.486)$ \\
\hline \multirow[t]{2}{*}{ LI*FI } & $0.010^{* *}$ & $0.007^{*}$ & -0.019 & -0.019 & $0.019^{*}$ & $0.022^{* *}$ & -0.014 & -0.019 & 0.009 & 0.007 & 0.009 & 0.008 \\
\hline & $(0.005)$ & $(0.004)$ & $(0.013)$ & $(0.012)$ & $(0.011)$ & $(0.011)$ & $(0.013)$ & $(0.012)$ & $(0.013)$ & $(0.013)$ & $(0.007)$ & $(0.007)$ \\
\hline \multirow[t]{2}{*}{$\mathrm{CC}$} & -0.062 & 0.017 & $-0.333^{*}$ & $-0.291 *$ & 0.007 & -0.097 & -0.117 & -0.110 & -0.171 & 0.031 & 0.150 & $0.326^{* * *}$ \\
\hline & $(0.017)$ & $(0.049)$ & $(0.188)$ & $(0.176)$ & $(0.082)$ & $(0.077)$ & $(0.207)$ & $(0.210)$ & $(0.133)$ & $(0.116)$ & $(0.105)$ & $(0.093)$ \\
\hline \multirow[t]{2}{*}{ CIR } & $-0.163^{* * *}$ & $-0.163^{* * *}$ & -0.101 & -0.097 & $-0.276^{* * *}$ & $-0.302^{* * *}$ & $-0.088^{* * *}$ & $-0.086^{* * *}$ & $-0.849^{* * *}$ & $-0.988^{* * *}$ & $-0.176^{* * *}$ & $-0.160^{* * * *}$ \\
\hline & $(0.017)$ & $(0.017)$ & $(0.118)$ & $(0.116)$ & $(0.063)$ & $(0.063)$ & $(0.020)$ & $(0.021)$ & $(0.139)$ & $(0.139)$ & $(0.019)$ & $(0.021)$ \\
\hline \multirow[t]{2}{*}{ Size } & $0.079 * * *$ & $0.107 * * *$ & 0.045 & $0.127^{* *}$ & $0.066^{*}$ & $0.077^{* *}$ & $0.070^{*}$ & $0.076^{*}$ & 0.043 & 0.003 & $0.051^{*}$ & $0.116^{* * *}$ \\
\hline & $(0.018)$ & $(0.016)$ & $(0.072)$ & $(0.062)$ & $(0.036)$ & $(0.034)$ & $(0.040)$ & $(0.040)$ & $(0.042)$ & $(0.038)$ & $(0.030)$ & $(0.028)$ \\
\hline \multirow[t]{2}{*}{ CAR } & $6.109^{* * *}$ & $5.930 * * *$ & $5.328 * * *$ & $5.171^{* * *}$ & $4.510^{* * *}$ & $4.514^{* * *}$ & $6.010^{* * *}$ & $5.853^{* * *}$ & $8.511^{* * *}$ & $7.797 * * *$ & $7.350 * * *$ & $6.643^{* * *}$ \\
\hline & $(0.164)$ & $(0.162)$ & $(0.403)$ & $(0.390)$ & $(0.226)$ & $(0.229)$ & $(0.428)$ & $(0.425)$ & $(0.531)$ & $(0.509)$ & $(0.321)$ & $(0.335)$ \\
\hline \multirow[t]{2}{*}{ LoanR } & 0.150 * & $0.133^{*}$ & $-0.419^{* *}$ & $-0.484^{* *}$ & -0.061 & -0.056 & $0.417^{* *}$ & $0.390^{* *}$ & 0.059 & 0.273 & 0.085 & 0.016 \\
\hline & $(0.081)$ & $(0.079)$ & (0.187) & $(0.181)$ & $(0.160)$ & $(0.159)$ & $(0.190)$ & $(0.191)$ & $(0.210)$ & $(0.206)$ & $(0.127)$ & $(0.135)$ \\
\hline \multirow[t]{2}{*}{ LonQ } & $-2.464^{* * * *}$ & $-2.511^{* * *}$ & $-1.313^{* *}$ & $-1.347^{* *}$ & $-1.655^{* *}$ & $-1.643^{* *}$ & $-1.879^{* * *}$ & $-1.812^{* * *}$ & $-3.375^{* * *}$ & $-3.704 * * *$ & $-3.363^{* * *}$ & $-3.903^{* * *}$ \\
\hline & $(0.259)$ & $(0.261)$ & $(0.609)$ & $(0.605)$ & $(0.549)$ & $(0.562)$ & $(0.390)$ & $(0.395)$ & $(0.533)$ & $(0.545)$ & $(0.629)$ & $(0.686)$ \\
\hline \multirow[t]{2}{*}{ Divers } & -0.006 & -0.006 & $0.697^{* * *}$ & $0.622^{* *}$ & $0.874^{* * *}$ & $0.799^{* * *}$ & 0.238 & 0.201 & -0.010 & -0.008 & -0.041 & -0.036 \\
\hline & (0.009) & $(0.009)$ & $(0.259)$ & $(0.255)$ & (0.194) & $(0.197)$ & $(0.174)$ & $(0.173)$ & $(0.015)$ & $(0.015)$ & $(0.044)$ & $(0.048)$ \\
\hline \multirow[t]{2}{*}{ GDPGPC } & -0.001 & -0.001 & -0.001 & -0.001 & $0.017^{* *}$ & $0.014^{* *}$ & -0.001 & -0.001 & $-0.010^{*}$ & $-0.011^{*}$ & 0.001 & 0.001 \\
\hline & $(0.001)$ & $(0.001)$ & $(0.001)$ & $(0.001)$ & $(0.007)$ & $(0.007)$ & $(0.004)$ & $(0.004)$ & $(0.006)$ & $(0.006)$ & $(0.004)$ & $(0.005)$ \\
\hline \multirow[t]{2}{*}{ Inflation } & $1.65 \mathrm{e}-6$ & $6.40 \mathrm{e}-7$ & $-0.013^{*}$ & $-0.013^{*}$ & $-0.006^{* * *}$ & $-0.005^{* *}$ & $0.009^{* *}$ & $0.010^{* *}$ & -0.003 & -0.005 & $3.84 \mathrm{e}-6$ & $2.53 e-6$ \\
\hline & $(5.85 \mathrm{e}-6)$ & $(5.93 \mathrm{e}-6)$ & $(0.007)$ & $(0.007)$ & $(0.002)$ & $(0.003)$ & $(0.004)$ & $(0.004)$ & $(0.004)$ & $(0.004)$ & $(4.72 \mathrm{e}-6)$ & $(5.18 \mathrm{e}-6)$ \\
\hline Hausman & 0.000 & 0.000 & 0.411 & 0.411 & 0.000 & 0.000 & 0.100 & 0.100 & 0.000 & 0.000 & 0.000 & 0.000 \\
\hline R-square & 0.474 & 0.472 & 0.584 & 0.581 & 0.547 & 0.544 & 0.664 & 0.663 & 0.506 & 0.499 & 0.621 & 0.609 \\
\hline F-stat. $X^{2}$ & $128.32 * * *$ & $1635.10^{* * * *}$ & $20.64^{* * *}$ & $274.18^{* * *}$ & $43.15^{* * *}$ & $538.23^{* * *}$ & $22.00^{* * *}$ & $274.62 * * *$ & $36.01 * * *$ & $453.54^{* * *}$ & $55.46^{* * *}$ & $584.66^{* * *}$ \\
\hline Banks & 354 & 354 & 51 & 51 & 80 & 80 & 31 & 31 & 91 & 91 & 80 & 80 \\
\hline Observs. & 2220 & 2220 & 255 & 255 & 557 & 557 & 189 & 189 & 561 & 561 & 534 & 534 \\
\hline
\end{tabular}

Notes: Robust standard errors are reported in parentheses. $* * *, * *$ implies statistical significance at $10 \%, 5 \%$, and $1 \%$, respectively and coefficients in bold are statistically significant. The diagnostic test reported include; (1) the Hausman specification test p-value; (2) the R square value; (3) F-statistic and Wald-chi to indicate the joint significance of the fixed and random effects models; (4) number of observations; and (5) the number of banks used in the estimation. The interaction term (LI*FI) and control of corruption (CC) proxy for the effects of the interaction between financial integration and competition for each sample and institutional quality on bank risk-taking behavior, respectively. 
Table 8. Effect of Regulation Quality on the Relationship between Financial Integration, Competition and Bank Risk-Taking

\begin{tabular}{|c|c|c|c|c|c|c|c|c|c|c|c|c|}
\hline & \multicolumn{2}{|c|}{ AFRICA } & \multicolumn{2}{|c|}{$\mathrm{AMU}$} & \multicolumn{2}{|c|}{ EAC } & \multicolumn{2}{|c|}{ ECCAS } & \multicolumn{2}{|c|}{ ECOWAS } & \multicolumn{2}{|c|}{ SADC } \\
\hline & $\mathrm{FE}$ & $\mathrm{RE}$ & $\mathrm{FE}$ & $\mathrm{RE}$ & $\mathrm{FE}$ & $\mathrm{RE}$ & $\mathrm{FE}$ & $\mathrm{RE}$ & $\mathrm{FE}$ & $\mathrm{RE}$ & $\mathrm{FE}$ & $\mathrm{RE}$ \\
\hline \multirow[t]{2}{*}{ Constant } & $0.985^{* * *}$ & $0.600^{* *}$ & 1.197 & -0.208 & $1.408^{* *}$ & $1.066^{* *}$ & 0.284 & 0.052 & $2.090^{* *}$ & $2.810^{* * *}$ & $1.493^{* *}$ & $0.798^{*}$ \\
\hline & $(0.265)$ & $(0.250)$ & (1.201) & $(0.995)$ & $(0.544)$ & $(0.517)$ & $(0.839)$ & $(0.768)$ & $(0.763)$ & $(0.674)$ & $(0.479)$ & $(0.477)$ \\
\hline \multirow[t]{2}{*}{ FI } & $-0.004^{*}$ & -0.002 & $0.018^{* *}$ & $0.018^{* *}$ & $-0.008^{* *}$ & $-0.006^{*}$ & -0.003 & -0.001 & -0.009 & -0.009 & -0.006 & -0.004 \\
\hline & $(0.002)$ & $(0.002)$ & $(0.006)$ & $(0.006)$ & $(0.004)$ & $(0.004)$ & $(0.017)$ & $(0.012)$ & $(0.006)$ & $(0.006)$ & $(0.005)$ & $(0.005)$ \\
\hline \multirow[t]{2}{*}{ LI } & $0.740^{* *}$ & $0.882 * * *$ & $1.144^{* *}$ & $1.039^{*}$ & -0.049 & -0.002 & 0.840 & $1.135^{*}$ & $1.140^{*}$ & 0.995 & 0.334 & 0.512 \\
\hline & $(0.248)$ & $(0.246)$ & $(0.537)$ & $(0.534)$ & $(0.522)$ & $(0.533)$ & $(0.690)$ & $(0.658)$ & $(0.707)$ & $(0.706)$ & $(0.400)$ & $(0.430)$ \\
\hline \multirow[t]{2}{*}{$\mathrm{LI}^{2}$} & $-1.460^{* * *}$ & $-1.450^{* * *}$ & -0.621 & -0.453 & $-1.217^{* *}$ & $-1.313^{* *}$ & 0.171 & 0.128 & $-2.525^{* * *}$ & $-2.22^{* * *}$ & $-0.760^{*}$ & $-0.790^{*}$ \\
\hline & $(0.257)$ & $(0.257)$ & $(0.729)$ & $(0.718)$ & $(0.458)$ & $(0.467)$ & $(0.575)$ & $(0.586)$ & $(0.597)$ & $(0.597)$ & $(0.450)$ & $(0.490)$ \\
\hline \multirow[t]{2}{*}{$\mathrm{LI} * \mathrm{FI}$} & $0.010^{* *}$ & $0.008^{*}$ & -0.020 & -0.019 & $0.019^{*}$ & $0.020^{*}$ & -0.014 & $-0.020^{*}$ & 0.010 & 0.009 & 0.009 & 0.007 \\
\hline & $(0.005)$ & $(0.004)$ & $(0.013)$ & $(0.012)$ & $(0.010)$ & $(0.011)$ & $(0.013)$ & $(0.012)$ & $(0.013)$ & $(0.013)$ & $(0.007)$ & $(0.007)$ \\
\hline \multirow[t]{2}{*}{ RQty } & 0.043 & $0.090^{*}$ & -0.037 & 0.022 & -0.099 & -0.083 & -0.071 & -0.089 & 0.199 & $0.433^{* *}$ & 0.004 & $0.176^{*}$ \\
\hline & $(0.057)$ & $(0.052)$ & $(0.098)$ & $(0.089)$ & $(0.110)$ & $(0.111)$ & $(0.188)$ & $(0.191)$ & $(0.223)$ & $(0.180)$ & $(0.126)$ & $(0.106)$ \\
\hline \multirow[t]{2}{*}{ CIR } & $-0.162^{* * *}$ & $-0.162^{* * *}$ & -0.082 & -0.080 & $-0.284^{* * *}$ & $-0.301^{* * *}$ & $-0.089 * * *$ & $-0.086^{* * *}$ & $-0.864^{* * *}$ & $-0.987^{* * *}$ & $-0.177^{* * *}$ & $-0.164^{* * *}$ \\
\hline & $(0.017)$ & $(0.017)$ & $(0.118)$ & $(0.116)$ & $(0.063)$ & $(0.064)$ & $(0.020)$ & $(0.021)$ & $(0.139)$ & (0.139) & $(0.019)$ & $(0.021)$ \\
\hline \multirow[t]{2}{*}{ Size } & $0.081 * * *$ & $0.104^{* * *}$ & 0.058 & $0.155^{* *}$ & $0.065^{*}$ & $0.085^{* *}$ & $0.075^{*}$ & $0.083^{* *}$ & 0.042 & -0.013 & 0.046 & $0.098^{* * *}$ \\
\hline & $(0.017)$ & $(0.016)$ & $(0.085)$ & $(0.068)$ & $(0.036)$ & $(0.033)$ & $(0.041)$ & $(0.041)$ & $(0.043)$ & $(0.037)$ & $(0.031)$ & $(0.029)$ \\
\hline \multirow[t]{2}{*}{ CAR } & $6.096^{* * *}$ & $5.921 * * *$ & $5.246^{* * *}$ & $5.116^{* * *}$ & $4.530^{* * *}$ & $4.531^{* * *}$ & $6.033^{* * *}$ & $5.861^{* * *}$ & $8.340^{* * *}$ & $7.718^{* * *}$ & $7.328^{* * *}$ & $6.567 * * *$ \\
\hline & $(0.164)$ & $(0.162)$ & $(0.403)$ & $(0.392)$ & $(0.227)$ & $(0.230)$ & $(0.425)$ & $(0.425)$ & $(0.538)$ & $(0.508)$ & $(0.321)$ & $(0.337)$ \\
\hline \multirow[t]{2}{*}{ LoanR } & $0.147^{*}$ & 0.116 & $-0.421^{* *}$ & $-0.484^{* *}$ & -0.056 & -0.031 & $0.425^{* *}$ & $0.397^{* *}$ & 0.049 & 0.206 & 0.094 & -0.012 \\
\hline & $(0.081)$ & $(0.080)$ & $(0.190)$ & $(0.183)$ & $(0.159)$ & $(0.158)$ & $(0.190)$ & $(0.193)$ & $(0.211)$ & $(0.207)$ & $(0.133)$ & $(0.139)$ \\
\hline \multirow[t]{2}{*}{ LonQ } & $-2.466^{* * *}$ & $-2.531^{* * *}$ & $-1.387^{* *}$ & $-1.440^{* *}$ & $-1.633^{* *}$ & $-1.576^{* *}$ & $-1.891^{k * *}$ & $-1.820^{* * * *}$ & $-3.419 * * *$ & $-3.762^{* * *}$ & $-3.472^{* * *}$ & $-4.166^{* * *}$ \\
\hline & $(0.259)$ & $(0.261)$ & $(0.614)$ & $(0.609)$ & $(0.548)$ & $(0.561)$ & $(0.390)$ & (0.399) & $(0.535)$ & $(0.544)$ & $(0.626)$ & $(0.686)$ \\
\hline \multirow[t]{2}{*}{ Divers } & -0.006 & -0.006 & $0.668^{* *}$ & $0.604^{* *}$ & $0.889^{* * *}$ & $0.830^{* * *}$ & 0.234 & 0.193 & -0.008 & -0.006 & -0.047 & -0.050 \\
\hline & $(0.009)$ & $(0.009)$ & $(0.260)$ & $(0.257)$ & $(0.194)$ & $(0.197)$ & $(0.174)$ & $(0.174)$ & $(0.015)$ & $(0.015)$ & $(0.043)$ & $(0.048)$ \\
\hline \multirow[t]{2}{*}{ GDPGPC } & -0.001 & -0.001 & -0.001 & -0.001 & $0.017^{* *}$ & 0.014 * & -0.001 & -0.001 & $-0.012 * *$ & $-0.013^{* *}$ & 0.001 & $6.03 e-5$ \\
\hline & $(0.001)$ & $(0.001)$ & $(0.001)$ & $(0.001)$ & $(0.007)$ & $(0.007)$ & $(0.003)$ & $(0.004)$ & $(0.006)$ & $(0.006)$ & $(0.004)$ & $(0.005)$ \\
\hline \multirow[t]{2}{*}{ Inflation } & $1.69 \mathrm{e}-6$ & $6.27 \mathrm{e}-7$ & $-0.014^{*}$ & $-0.013^{*}$ & -0.006 & -0.006 & $0.009^{* *}$ & $0.010^{* *}$ & -0.004 & $-0.007^{*}$ & $3.52 \mathrm{e}-6$ & $1.61 \mathrm{e}-6$ \\
\hline & $(5.85 \mathrm{e}-6)$ & $(5.92 \mathrm{e}-6)$ & $(0.008)$ & $(0.007)$ & $(0.002)$ & $(0.003)$ & $(0.004)$ & $(0.004)$ & $(0.004)$ & $(0.004)$ & $(4.73 e-6)$ & $(5.21 \mathrm{e}-6)$ \\
\hline Hausman: & 0.000 & 0.000 & 0.426 & 0.426 & 0.000 & 0.000 & 0.043 & 0.043 & 0.000 & 0.000 & 0.000 & 0.000 \\
\hline R-Square & 0.474 & 0.472 & 0.578 & 0.574 & 0.548 & 0.547 & 0.663 & 0.662 & 0.505 & 0.501 & 0.619 & 0.607 \\
\hline F-stat. $/ \mathrm{X}^{2}$ & $128.22^{* * *}$ & $1639.10^{* * *}$ & $20.10^{* * * *}$ & $267.73^{* * *}$ & $43.28^{* * * *}$ & $537.64^{* * *}$ & $21.96^{* * *}$ & $268.94^{* * *}$ & $35.87^{* * *}$ & $462.53^{* * *}$ & $\mathbf{5 5 . 0 5}^{* * *}$ & $567.27^{* * *}$ \\
\hline Banks & 354 & 354 & 51 & 51 & 80 & 80 & 31 & 31 & 91 & 91 & 80 & 80 \\
\hline Observs. & 2220 & 2220 & 255 & 255 & 557 & 557 & 189 & 189 & 561 & 561 & 534 & 534 \\
\hline
\end{tabular}

Notes: Robust standard errors are reported in parentheses. *,*, *** implies statistical significance at $10 \%, 5 \%$, and $1 \%$, respectively and coefficients in bold are statistically significant. The diagnostic test reported include; (1) the Hausman specification test p-value; (2) the R square value; (3) F-statistic and Wald-chi to indicate the joint significance of the fixed and random effects models; (4) number of observations; and (5) the number of banks used in the estimation. The interaction term (LI*FI) proxies the effects of the interaction between financial integration and bank competition and a second proxy is included for institutional quality, regulatory quality (RQty) to assess the effect of quality regulatory environments on bank risk-taking behavior in African banking markets.

\section{Conclusion}

This study examines the effect of financial integration and bank competition changes on bank risk-taking behavior in 47 African countries. comparing the results across five regional 
economic communities over 2007-2014. The results regarding the direct effect of financial freedom on bank risk-taking behavior support the integration-fragility theory in Africa, especially in the EAC. However, in the AMU, evidence supports the financial integration-stability theory. The evidence on the effect of competition on bank risk-taking behavior supports the MMR theory, indicating that bank competition increases bank risk-taking behavior, but beyond a certain threshold, further rise in bank competition reduces bank risk-taking behavior in Africa and all its sub-regional markets. The results also suggest that competition changes from increased financial integration enhances bank stability in Africa. Therefore, it can be concluded that African economies are unable to fully benefit from the stability of financial integration due to the lack of competitiveness in banking systems. The results on the effect of control variables suggest that bank capitalization, management quality, and loan quality reduce bank risk-taking behavior and promote bank stability in Africa. Bank size and loan ratio also have a significant influence on reducing bank fragility, implying that in the presence of increasing financial freedom, large banks are better able to diversify loan portfolios to remain stable. The analysis further shows that revenue diversification in Africa significantly reduces bank fragility, especially in the AMU, EAC, and ECCAS banking systems. However, inflation increases bank non-performing loans, especially in the ECOWAS and SADC banking systems.

These findings have significant policy implications for academics, bank managers, regulators, and policymakers. First, contrary to the view that a more liberalized and competitive banking system enhance bank stability, these results suggest that increasing local and foreign participation in banking markets through greater financial freedom may be detrimental to bank stability up to a certain threshold, beyond which further competition changes induced by greater financial liberalization will enhance stability. Sub-regional evidence also shows that policy initiatives need to be tailored for the specific conditions in each regional economic community, as they form the epicenters of financial integration in Africa, and any wholesale, continent-wide policies may not produce equivalent results. Our results also show that regulatory authorities should continue to ensure that banks in Africa maintain adequate capital levels, and high-quality managers to enhance stability. The maintenance of high-quality loan portfolios and a diversified income portfolio should also be encouraged among banks in Africa.

Whereas these findings may provide some useful insights, the study is not without limitations. Further studies could examine the various thresholds beyond which further integration-induced competition reduces bank risk-taking behavior in Africa. These findings also provide guidance for further research on the channels through which an optimal resolution of the trilemma between greater financial integration, market competitiveness, and financial stability can be achieved for higher economic growth. 


\section{References}

African Development Bank. (2010). Financial sector integration in three regions of Africa: How regional financial integration can support growth, development, and poverty reduction. Technical Report. Cote D'Ivoire.

Agoraki, M. E., Delis, M., \& Pasiouras, F. (2011). Regulations, competition and bank risk-taking in transition countries. Journal of Financial Stability, 7(1), 38-48.

Amidu, M., \& Wolfe, S. (2013). Does bank competition and diversification lead to greater stability? Evidence from emerging markets. Review of Development Finance, 3(3), 152-166.

Banyen, K., \& Biekpe, N. (2020). Financial integration, competition and bank efficiency: Evidence from Africa's sub-regional markets. Economic Change and Restructuring, 2020, 1-24. https://doi.org/10.100 7/s10644-019-09262-8

Beck, T., \& Cull, R. (2014). Banking in Africa. In A. N. Berger, P. Molyneux, \& J. O. S. Wilson (Eds.), Oxford Handbook of Banking (2nd ed.). Oxford: Oxford University Press.

Beck, T., De Jonghe, O., \& Schepens, G. (2013). Banking competition and stability: Cross-country heterogeneity. Journal of Financial Intermediation, 22, 218-244.

Beck, T., Demirgüç-Kunt, A., \& Levine, R. (2006). Bank concentration, competition, and crises: First results. Journal of Banking and Finance, 30(5), 1581-1603.

Beck, T., Maimbo, S. M., Faye, I., \& Triki, T. (2011). Financing Africa through the crisis and beyond. Washington, DC: World Bank.

Berger, A. N., Klapper, L. F., \& Turk-Ariss, R. (2009). Bank competition and financial stability. Journal of Financial Services Research, 35, 99-118.

Bourgain, A., Pieretti, P., \& Zanaj, S. (2012). Financial Openness, Disclosure and Bank risk-taking in MENA countries. Emerging Markets Review, 13, 283-300.

Boyd, J. H., \& De Nicoló, G. (2005). The Theory of Bank Risk-Taking and Competition Revisited. Journal of Finance, 60(3), 1329-1343.

Brambor, T., Clark, W. R., \& Golder, M. (2006). Understanding Interaction Models: Improving Empirical Analyses. Political Analysis, 14, 63-82.

Brei, M., Jacolin, L., \& Noah, A. (2018). Credit risk and bank competition in Sub-Saharan Africa. Banque de France Working Paper No. 664. February 2018. Available at https://publications.banque-france.fr/sit es/default/files/medias/documents/wp664_0.pdf

Cubillas, E., \& González, F. (2014). Financial liberalization and bank risk-taking: International evidence. Journal of Financial Stability, 11(3), 32-48.

Caminal, R., \& Matutes, C. (2002). Market power and bank failures. International Journal of Industrial Organization, 20, 1341-1361.

Coccorese, P. (2014). Estimating the Lerner index for the banking industry: a stochastic frontier approach. Applied Financial Economics, 24(2), 73-88.

Farroukh, A. (2013). Financial Integration, Banking Competition Changes and Financial Stability: The Case of the MENA Region. Financial and Monetary Policy Studies, 36, 173-193.

Fiordelisi, F., \& Mare, D. S. (2014). Competition and financial stability in European cooperative banks. 
Journal of International Money and Finance, 45, 1-16.

Fu, X. M., Lin, Y. R., \& Molyneux, P. (2014). Bank competition and financial stability in Asia Pacific. Journal of Banking and Finance, 38(C), 64-77.

Goetz, M. R. (2017). Competition and bank stability. Journal of Financial Intermediation. http://dx.doi.org/ 10.1016/j.jfi.2017.06.001

Hamdaoui, M., Zouari, A., \& Maktouf, S. (2016). The effect of financial liberalization on banking sector stability. International Review of Applied Economics, 30(5), 644-667.

Hughes, J., \& L. Mester. (1993). A quality and risk-adjusted cost function for banks: Evidence on the "too-big-to-fail" doctrine. Journal of Productivity Analysis, 4(3), 293-315.

Jiménez, G., López, J. A., \& Saurina, J. (2013). How does competition affect bank risk-taking? Journal of Financial Stability, 9, 185-195.

Joyce, J. (2011). Financial globalization and banking crisis in emerging markets. pen Economies Review, 22(5),875-895.

Kabir, M. N., \& Worthington, A. C. (2017). The 'competition-stability/fragility 'nexus: A comparative analysis of Islamic and conventional banks. International Review of Financial Analysis, 50(1), 11-128.

Kasman, S., \& Kasman, A. (2015). Bank competition, concentration and financial stability in the Turkish banking industry. Economic Systems, 39(3), 502-517.

Keeley, M. (1990). Deposit insurance, risk and market power in banking. American Economic Review, 80, 1183-1200.

Kennedy, P. (2008). A guide to econometric (6th ed.). Malden, MA: Blackwell.

Leon, F. (2016). Does the Expansion of Regional Cross-border Banks Affect Competition in Africa? Indirect Evidence. Research in International Business and Finance, 37, 66-77.

Li, X., \& Su, D. (2016). Capital Account Liberalization and Bank Risk: Bank Level Evidence. Available at https://editorialexpress.com/cgi-bin/conference/download.cgi?db_name=RESConf2017\&paper_id=956

Liu, H., Molyneux, P., \& Nguyen, L. H. (2012). Competition and risk in South East Asian commercial banks. Applied Economics, 44(28), 3627-3644.

Marcus, A. J. (1984). Deregulation and bank financial policy. Journal of Banking and Finance, 8(4), 557-565.

Martinez-Miera, D., \& Repullo, R. (2010). Does competition reduce the risk of bank failure? Review of Financial Studies, 23(10), 3638-3664.

Motelle, S., \& Biekpe, N. (2014). Financial integration and stability in the Southern African Development Community. Journal of Economics and Business, 79, 100-117.

Moyo, J., Nandwa, B., Oduor, J., \& Simpasa, A. (2014). Financial sector reforms, competition and banking system stability in Sub-Saharan Africa. Paper presented at the joint RES-SPR Conference on "Macroeconomic Challenges Facing Low-Income Countries". International Monetary Fund, Washington, DC-January 30-31, 2014.

Ndomo, A. (2009). Regional Economic Communities in Africa: A progress overview. Study commissioned by the GTZ, Nairobi, May 2009. Available at: http://www2.giz.de/wbf/4tDx9kw63gma/RECs_Final_Re port.pdf

Norman, A. H. M., Gee, C. S., \& Isa, C. R. (2018). Does bank regulation matter on the relationship 
between competition and financial stability? Evidence from Southeast Asian countries. Pacific-Basin Finance Journal, 48, 144-161.

Rossi, M. (1999). Financial fragility and economic performance in developing economies: Do capital controls, prudential regulation and supervision matter? IMF Working Paper no.99/66. Washington, DC: IMF.

Rupello, R. (2004). Capital Requirements, Market Power, and Risk-Taking in Banking. Journal of Financial Intermediation, 13, 156-182.

Schoemaker, D. (2011). The financial trilemma. Tinbergen Institute Discussion Paper, No. 11-019/2/DSF 7, Tinbergen Institute, Amsterdam and Rotterdam.

Schaeck, K., \& Cihák, M. (2014). Competition, efficiency, and stability in banking. Financial Management, 43(1), 215-241.

Shijaku, G. (2017). Does concentration matter for bank stability? Evidence from Albanian banking sector. Journal of Central Banking Theory and Practice, 6(3), 67-94.

Sissy, A. M., Amidu, M., \& Abor, J. Y. (2017). The effects of revenue diversification and cross border banking on risk and return of banks in Africa. Research in International Business and Finance, 40, $1-18$.

Smaga, P. (2014). The concept of systemic risk. Systemic Risk Centre Special Paper No.5. London School of Economics and Political Science, London, UK.

Soedarmono, W., \& Tarazi, A. (2016). Competition, financial intermediation, and riskiness of banks: Evidence from the Asia-Pacific Region. Emerging Markets Finance and Trade, 52, 961-974.

Soedarmono, W., Machrouh, F., \& Tarazi, A. (2013). Bank competition, crisis and risk taking: Evidence from emerging markets in Asia. Journal of International Financial Markets, Institutions and Money, 23, 196-221.

Tabak, B. M., Fazio, D. M., \& Cajueiro, D. O. (2012). The relationship between banking market competition and risk-taking: Do size and capitalization matter? Journal of Banking and Finance, 36(12), 3366-3381.

Tabak, B. M., Gomes, G. M., \& da Silva Medeiros, M. (2015). The impact of market power at bank level in risk-taking: The Brazilian case. International Review of Financial Analysis, 4, 154-165.

Turk-Ariss, R. (2010). On the implications of market power in banking: Evidence from developing countries. Journal of Banking and Finance, 34(4), 765-775.

World Bank. (2007). Financial sector integration in two regions of Sub-Saharan Africa. January, Washington DC. 


\section{Appendix}

Table A. Country Composition of Study Sample by Regional Economic Community (REC)

\begin{tabular}{|c|c|c|c|c|}
\hline REC & Country & Number of Banks & Country & No. of Banks \\
\hline \multirow{3}{*}{ AMU } & Algeria & 14 & Morocco & 11 \\
\hline & Libya & 8 & Tunisia & 15 \\
\hline & Mauritania & 6 & & \\
\hline \multirow{3}{*}{ EAC } & Burundi & 3 & South Sudan & 3 \\
\hline & Kenya & 27 & Tanzania & 26 \\
\hline & Rwanda & 8 & Uganda & 16 \\
\hline \multirow{3}{*}{ ECCAS } & Angola & 15 & Chad & 3 \\
\hline & Cameroon & 5 & DRC & 11 \\
\hline & Central African Republic & 2 & Gabon & 5 \\
\hline \multirow{7}{*}{ ECOWAS } & Benin & 5 & Liberia & 3 \\
\hline & Burkina & 8 & Mali & 6 \\
\hline & Cape Verde & 6 & Niger & 3 \\
\hline & Cote D'Ivoire & 6 & Nigeria & 21 \\
\hline & Gambia & 4 & Senegal & 9 \\
\hline & Ghana & 19 & Sierra Leone & 7 \\
\hline & Guinea & 3 & Togo & 3 \\
\hline \multirow{6}{*}{ SADC } & Botswana & 7 & Namibia & 4 \\
\hline & Lesotho & 3 & Seychelles & 4 \\
\hline & Madagascar & 4 & South Africa & 12 \\
\hline & Malawi & 5 & Swaziland & 4 \\
\hline & Mauritius & 11 & Zambia & 14 \\
\hline & Mozambique & 7 & Zimbabwe & 9 \\
\hline \multirow{2}{*}{ Others } & Djibouti & 4 & Ethiopia & 9 \\
\hline & Egypt & 21 & Sudan & 6 \\
\hline Totals & Countries & 47 & Banks & 405 \\
\hline
\end{tabular}

(Source) Author's collation of data from Bankscope database (2016)

Table B. Sub-regional Summary of Lerner Index Input and Output Variables

\begin{tabular}{ccccccccc}
\hline REC & AR & W1 & W2 & W3 & TC & YTA & EQ & MC \\
\hline AMU & 0.0586055 & 0.0096484 & 0.9786734 & 0.0192775 & 150757.3 & 4934494 & 533885.1 & 0.0345179 \\
\hline EAC & 0.1232441 & 0.0289684 & 1.869092 & 0.0467415 & 30710.04 & 378792 & 56028.78 & 0.1061419 \\
\hline ECCAS & 0.1079368 & 0.0216124 & 1.568615 & 0.0194602 & 63996.06 & 1049252 & 126605 & 0.0872157 \\
\hline ECOWAS & 0.1162368 & 0.022072 & 1.476843 & 0.0432562 & 106302.1 & 1296216 & 187614.8 & 0.0877382 \\
\hline SADC & 0.1240021 & 0.0267893 & 2.351427 & 0.0526478 & 323465.8 & 4585242 & 353811.3 & 0.0914988 \\
\hline AFRICA & 0.1075302 & 0.021701 & 1.666357 & 0.0399346 & 151662.1 & 2537843 & 250781 & 0.0846648 \\
\hline
\end{tabular}

(Source) Authors' estimation from Bank scope data for 405 banks across 47 African countries for 2007-2014. All variables are as explained under equation 6 . 